\title{
On the Changing Contribution of Snow to the Hydrology of the Fraser River Basin, Canada
}

\author{
Do HYUK KANG \\ Environmental Science and Engineering Program, University of Northern British Columbia, Prince George, \\ British Columbia, Canada \\ XIAOGANG SHI \\ National Hydrology Research Centre, Environment Canada, Saskatoon, Saskatchewan, Canada \\ HUILIN GAO \\ Zachry Department of Civil Engineering, Texas A\&M University, College Station, Texas
}

STEPHEN J. DÉRY

Environmental Science and Engineering Program, University of Northern British Columbia, Prince George, British Columbia, Canada

(Manuscript received 23 July 2013, in final form 11 February 2014)

\begin{abstract}
This paper presents an application of the Variable Infiltration Capacity (VIC) model to the Fraser River basin (FRB) of British Columbia (BC), Canada, over the latter half of the twentieth century. The Fraser River is the longest waterway in $\mathrm{BC}$ and supports the world's most abundant Pacific Ocean salmon populations. Previous modeling and observational studies have demonstrated that the FRB is a snow-dominated system, but with climate change, it may evolve to a pluvial regime. Thus, the goal of this study is to evaluate the changing contribution of snow to the hydrology of the FRB over the latter half of the twentieth century. To this end, a $0.25^{\circ}$ atmospheric forcing dataset is used to drive the VIC model from 1949 to 2006 (water years) at a daily time step over a domain covering the entire FRB. A model evaluation is first conducted over 11 major subwatersheds of the FRB to quantitatively assess the spatial variations of snow water equivalent (SWE) and runoff $(R)$. The ratio of the spatially averaged maximum SWE to $R\left(R_{\mathrm{SR}}\right)$ is used to quantify the contribution of snow to the runoff in the 11 subwatersheds of interest. From 1949 to $2006, R_{\mathrm{SR}}$ exhibits a significant decline in 9 of the 11 subwatersheds (with $p<0.05$ according to the Mann-Kendall test statistics). To determine the sensitivity of $R_{\mathrm{SR}}$, the air temperature and precipitation in the forcing dataset are then perturbed. The ratio $R_{\mathrm{SR}}$ decreases more significantly, especially during the 1990 s and 2000 s, when air temperatures have warmed considerably compared to the $1950 \mathrm{~s}$. On the other hand, increasing precipitation by a multiplicative factor of 1.1 causes $R_{\mathrm{SR}}$ to decrease. As the climate continues to warm, ecological processes and human usage of natural resources in the FRB may be substantially affected by its transition from a snow to a hybrid (nival/ pluvial) and even a rain-dominated system.
\end{abstract}

\section{Introduction}

The presence of a seasonal snowpack in western Canada forms an essential component of its regional

\footnotetext{
Corresponding author address: Do Hyuk Kang, Postdoctoral Fellow, Environmental Science and Engineering Program, University of Northern British Columbia, Prince George, BC V2N 4Z9, Canada. E-mail: dkang@unbc.ca
}

water resources and also serves as a sensitive indicator of climate change. Peak flows of the Fraser River of British Columbia (BC) and its many tributaries usually occur in late spring and early summer and are driven by snowmelt, especially at high elevations (Moore and Wondzell 2005). The Fraser River basin (FRB) is a snow-dominated system (Morrison et al. 2002), but significant declines of snow accumulations have been reported over recent decades, especially in its lowlands 
and interior plateaus (Slaymaker 1990; Danard and Murty 1994). Therefore, the FRB may now be transitioning to a hybrid, and perhaps even a rain-dominated, system, as climate model projections are suggesting (Morrison et al. 2002; Ferrari et al. 2007; Shrestha et al. 2012). Despite ongoing changes, the Fraser River continues to provide vast forest resources for the lumber industry, a source of hydroelectric generation, and numerous places of recreation along its waterways (Fraser Basin Council 2006, 2009). The Fraser is the seventh largest river in North America by annual discharge and is also one of the most prolific salmon rivers in the world, with many First Nations relying on the annual upriver migrations for nourishment (Xie and Hsieh 1989; Beamish et al. 1997; Benke and Cushing 2005; Fraser Basin Council 2006, 2009). However, Rand et al. (2006) demonstrate how extremes in flows can lead to high mortality rates in sockeye salmon migrating up the Fraser River. Thus, there may be significant impacts of climate change on the hydrologic regime of the Fraser River with implications to aquatic species and habitat, local communities, and the economy of western Canada.

There have been some recent efforts investigating the impacts of climate change on snow and its contribution to the hydrology of western North America. Mote et al. (2005) find a general declining trend in 1 April snow water equivalent (SWE) across western North America from 1925 to 2000 driven mainly by rising air temperatures but also decreasing precipitation amounts. Park et al. (2012) reveal declining trends in snow depth across North America between 1948 and 2006 while Choi et al. (2010) show a marked decline in snow cover duration in BC from 1972 to 2008. Hsieh and Tang (2001) reveal the influence of large-scale teleconnections on 1 April snowpack accumulations in the upper Columbia River basin, with cool phases of the El Niño-Southern Oscillation and the Pacific-North American pattern yielding large positive SWE anomalies. Danard and Murty (1994) report a $2.4 \mathrm{~mm} \mathrm{yr}^{-1}$ decline in SWE across the FRB between 1966 and 1989 concurrent with streamflow decreases in October. Déry et al. (2012) compile a comprehensive runoff dataset for 139 sites across the watershed spanning a century (1911-2010) and concluded that there is increasing interannual variability in runoff across many streams and rivers in the FRB, providing evidence of recent extremes in flows detrimental to salmon. A recent modeling effort by Shrestha et al. (2012) also found the FRB may transition to a hybrid (pluvial/nival) river system from its current state of a snow-dominated regime by the end of the twenty-first century, with the interior plateau becoming a rainfalldominated system. While these studies provide important information on the changing snow conditions and streamflow across western North America, to our knowledge no study has focused on the spatially integrated SWE across the entire FRB and its contribution to runoff generation in the latter half of the twentieth century.

To expand on these recent observational and modeling studies, this effort uses the Variable Infiltration Capacity (VIC) model (Liang et al. 1994, 1996) to conduct retrospective simulations of the FRB's hydrology for water years (1 October to 30 September of the following calendar year) 1949-2006. The model simulations focus on two aspects: 1) a VIC simulation of SWE and runoff $(R)$ driven by an observation-based forcing dataset and 2) VIC simulations with perturbed air temperatures and precipitation to evaluate possible hydrologic implications of climate change. A main objective of this paper is thus to assess the changing contribution of snow to runoff generation in the FRB during the latter part of the twentieth century and its sensitivity to air temperature and precipitation variability. To this end, the spatial variations of simulated SWE and $R$ are first validated with daily observations from snow pillow stations and hydrometric gauges, respectively. A novel aspect of this work is the development of the ratio of the spatially averaged maximum SWE to $R\left(R_{\mathrm{SR}}\right)$ that is then used to evaluate the direct contribution of snow to runoff generation over a given water year for the FRB.

The paper is structured as follows. Section 2 describes the FRB's geography, climate, and hydrology, and section 3 describes the VIC model, its setup for the FRB, and the forcing dataset. Section 3 details the observational datasets used to evaluate SWE and $R$ simulated by the VIC model. Section 4 then describes the model calibration process using observed streamflow and how the forcing datasets are perturbed to assess the hydrological responses in a changing climate and introduces the Mann-Kendall test statistics to evaluate trends in hydrometeorological variables, including $R_{\mathrm{SR}}$. Section 5 provides the results for water year maximum SWE, $R$, and $R_{\mathrm{SR}}$ in 11 major subwatersheds across the FRB. Sensitivity tests with perturbed forcing datasets are also presented in section 5. The paper ends with a discussion in section 6 on the hydrologic impacts of climate changes in the FRB and directions for future work.

\section{Study area}

The $240000 \mathrm{~km}^{2}$ FRB has 13 major subwatersheds (11 of which are well monitored by hydrometric gauge stations; see Table 1 for subbasin and station identification) and covers the mountainous terrain of the Coast and Rocky Mountains (Figs. 1a,b). The headwaters of the Fraser River originate in the Rocky Mountains near 
TABLE 1. List of hydrometric stations maintained by the Water Survey of Canada with subbasin characteristics (Déry et al. 2012).

\begin{tabular}{|c|c|c|c|c|c|c|c|}
\hline Subbasin & Gauge location name & $\begin{array}{l}\text { Mean basin } \\
\text { elev }(\mathrm{m})\end{array}$ & $\begin{array}{c}\text { Gauged } \\
\text { area }\left(\mathrm{km}^{2}\right)\end{array}$ & $\begin{array}{c}\text { Glacier } \\
\text { coverage }(\%)\end{array}$ & $\begin{array}{l}\text { Lat } \\
\left({ }^{\circ} \mathrm{N}\right)\end{array}$ & $\begin{array}{l}\text { Lon } \\
\left({ }^{\circ} \mathrm{W}\right)\end{array}$ & $\begin{array}{c}\text { Years of } \\
\text { availability }\end{array}$ \\
\hline Stuart (SU) & $\begin{array}{l}\text { Stuart River near Fort } \\
\text { St. James }\end{array}$ & 1097 & 14200 & 0.0 & 54.42 & 124.27 & 1929-2010 \\
\hline Nautley (NA) & Nautley River near Fort Fraser & 1070 & 6030 & 0.1 & 54.08 & 124.59 & $1950-2010$ \\
\hline Fraser-Shelley (UF) & Fraser River at Shelley & 1413 & 32400 & 3.0 & 54.01 & 122.62 & 1950-2010 \\
\hline Quesnel (QU) & Quesnel River near Quesnel & 1391 & 11500 & 2.3 & 52.84 & 122.22 & 1939-2010 \\
\hline Chilcotin $(\mathrm{CH})$ & Chilko River near Redstone & 1756 & 6940 & 6.8 & 52.07 & 123.54 & $1927-2010$ \\
\hline $\begin{array}{l}\text { North Thompson } \\
\text { (NT) }\end{array}$ & $\begin{array}{l}\text { North Thompson River at } \\
\text { McLure }\end{array}$ & 1489 & 19600 & 2.7 & 51.04 & 120.24 & $1958-2010$ \\
\hline $\begin{array}{l}\text { South Thompson } \\
\text { (ST) }\end{array}$ & $\begin{array}{l}\text { South Thompson River at } \\
\text { Chase }\end{array}$ & 1316 & 16200 & 0.6 & 50.76 & 119.74 & $1911-2010$ \\
\hline $\begin{array}{l}\text { Thompson-Nicola } \\
\text { (TN) }\end{array}$ & $\begin{array}{l}\text { Thompson River near } \\
\text { Spences Bridge }\end{array}$ & 1363 & 54900 & 1.1 & 50.35 & 121.39 & $1911-2010$ \\
\hline Fraser-Hope (LF1) & Fraser River at Hope & - & 217000 & - & 49.38 & 121.45 & $1912-2010$ \\
\hline $\begin{array}{l}\text { Lillooet-Harrison } \\
\quad(\mathrm{LH})\end{array}$ & $\begin{array}{l}\text { Harrison River near Harrison } \\
\text { Hot Springs }\end{array}$ & 1410 & 7870 & 8.3 & 49.31 & 121.80 & $1951-2010$ \\
\hline Fraser-Mission (LF2) & Fraser River at Mission & - & 228000 & - & 49.12 & 122.30 & $1965-92$ \\
\hline
\end{tabular}

Jasper, Alberta, with its tallest peak being Mount Robson at $3954 \mathrm{~m} \mathrm{MSL}$. Some of the major tributaries of the Fraser River are the Nechako, Quesnel, Chilcotin, and Thompson Rivers within the interior plateau. Descending through the Fraser Canyon, the Fraser River reaches Hope, BC, and then veers westward into the Salish Sea and the Strait of Georgia at Vancouver, BC (Benke and Cushing 2005; Evendon 2004; Fraser Basin Council 2006, 2009). The central sections of the Fraser River are mostly forested, but the area also includes grassland vegetation and large cattle farms in the relatively dry interior plateau while glaciers abound in the Rocky, Cariboo, and Coast Mountains (Bocking 1997). The main stem Fraser River has no impoundments, but the $\sim 45000 \mathrm{~km}^{2}$ Nechako
River basin, a main tributary in the northwestern part of the FRB, is a heavily regulated system (Hartman 1996; Schiefer and Klinkenberg 2004). During the 1950s, a large, earth-filled dam was built to regulate the flow of the Nechako River and to divert water to the coastal Kemano River to generate hydropower for an aluminum smelter in Kitimat, BC (Hartman 1996). The volume contained in the reservoir controlled by Kenney Dam is $32.7 \mathrm{~km}^{3}$ (Schiefer and Klinkenberg 2004) and the area upstream of the dam covers $15600 \mathrm{~km}^{2}$, or $6.5 \%$ of the entire FRB area (Déry et al. 2012).

Across the FRB (Benke and Cushing 2005), mean annual air temperatures vary from $0.5^{\circ} \mathrm{C}$ in the northwestern boundary in the Skeena Mountains to $7.5^{\circ} \mathrm{C}$ in

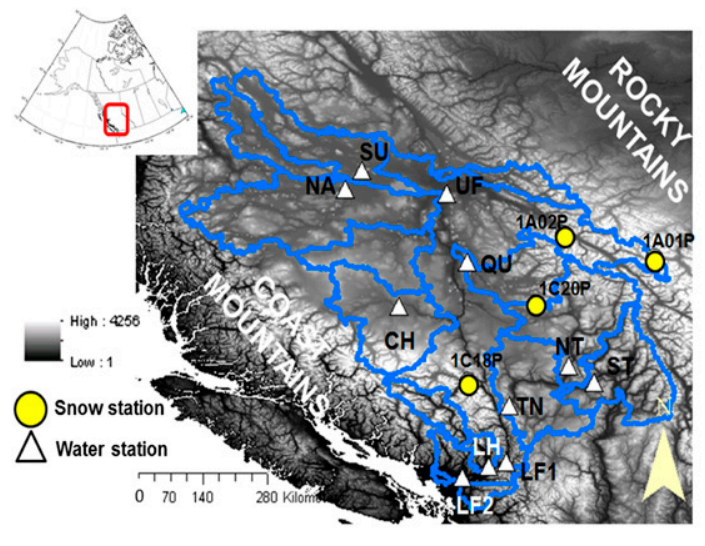

(a)

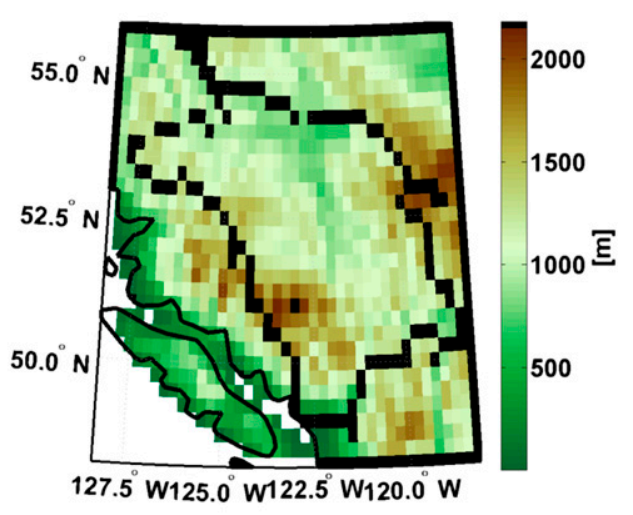

(b)

FIG. 1. Maps of the FRB. (a) High-resolution digital elevation map with identification of major subwatersheds: SU, NA, UF, QU, CH, NT, ST, TN, LF1, LH, and LF2 (Table 1). Labels starting with "1" refer to BC River Forecast Centre snow pillow sites used in the study (see Table 4). (b) VIC model domain for the FRB (black line) with $0.25^{\circ}$ resolution. 
the south near the Okanagan area. The ranges of mean summer air temperature in the FRB are less variable $\left(11^{\circ}\right.$ to $\left.16.5^{\circ} \mathrm{C}\right)$ than the winter mean air temperature $\left(-11^{\circ}\right.$ to $\left.-1^{\circ} \mathrm{C}\right)$. Precipitation is highly variable across the study domain. Coastal and mountainous areas receive abundant precipitation amounts of up to $3000 \mathrm{~mm} \mathrm{yr}^{-1}$ while the interior plateau and regions to the lee of the Coast Mountains receive $400-800 \mathrm{~mm} \mathrm{yr}^{-1}$. In the northern and mountainous regions of the FRB, snowfall plays an important role in precipitation. Because of its highly varying terrain and climate, the FRB includes various vegetation and land cover types ranging from alpine terrain, subalpine, and montane and coastal forests, with drier inland forests and grasslands in the interior plateau (Benke and Cushing 2005).

\section{Model and data}

\section{a. VIC model and its setup for application to the FRB}

The VIC (version 4.1.2) model (Liang et al. 1994, 1996) with more recent modifications (Cherkauer et al. 2003; Bowling et al. 2004; Bowling and Lettenmaier 2010) has been widely applied to assess water resources, landatmosphere interactions, and hydrological responses to weather and climate over various river basins around the world (Nijssen et al. 2001; Maurer et al. 2002; Haddeland et al. 2007; see also H. Gao et al. 2014, unpublished manuscript, for a current summary of VIC developments). As climate change has been a critical issue since the 1990s, VIC has also been extensively used with various forcing datasets provided by outputs from climate and weather prediction models (Wang et al. 2008; Shukla et al. 2012; 2013). VIC is a semidistributed, macroscale hydrology model that resolves energy and mass balances within a grid cell. To consider subgrid variability of the land surface, VIC uses a statistical approach to cope with different land and soil types that control soil moisture storage capacity. After solving the energy and mass balances using a partitioned vegetation tile in a grid cell, base flow and runoff are determined at the end of the time step. After running all the grid cells in a watershed using VIC, the external routing model is employed to extract the runoff at the designated cell, which is usually an outlet point of the given watershed or subwatershed (Lohmann et al. 1996, 1998a,b).

Model grid cells to cover the entire FRB are composed of 34 rows and 42 columns with a $7^{\circ}$ range of latitudes $\left(48^{\circ}-55^{\circ} \mathrm{N}\right)$ and a $12^{\circ}$ range of longitudes $\left(119^{\circ}-\right.$ $\left.131^{\circ} \mathrm{W}\right)$. Different tiles with each fraction characterized with soil and vegetation are proportionally partitioned within a grid cell. For the FRB application, three soil layers are used. The multi-institution North American
Land Data Assimilation System (NLDAS) datasets include water infiltration characteristics in soil such as field capacity, wilting point, saturated and hydraulic conductivity (Cosby et al. 1984). Using the land cover map based on Advanced Very High Resolution Radiometer (AVHRR) data (Hansen et al. 2000), the vegetation parameters are estimated using the method described in Sheffield and Wood (2007). The soil parameters generally fall into two categories. The first category of soil parameters is not adjusted once it is determined. Such parameters (e.g., soil texture information and soil bulk densities) are derived from the 5-min Food and Agriculture Organization dataset (FAO 2003). Another category of soil parameters is subject to calibration based on the agreement between simulated and observed hydrographs (Mitchell et al. 2004). Among various land cover properties, the leaf area index (LAI) is derived from Myneni et al. (1997) and is inverted from Hansen et al. (2000). These LAI values are the monthly means that do not represent the interannual variability of LAI changes. Rooting depth of the trees varies with LAI. For example, a short grass only root-uptakes the soil moisture from the top layer.

For the snow hydrology process, the albedo follows the U.S. Army Corps of Engineers empirical snow albedo decay curve (USACE 1956). The total amount of precipitation is distributed based on the global $0.25^{\circ}$ grid cell, and the air temperature is also adjusted with a lapse rate to determine the precipitation type. Ten 100-m elevation bands are used in the simulation to account for air temperature changes with elevation and impacts on precipitation phases. Note also that lakes, reservoirs, and wetlands are not considered in this VIC model application to the FRB. Future work will incorporate these components that may be especially important for the simulation of streamflow in the Nechako River, where there is a large impoundment of water for hydropower generation (Hartman 1996). In this subbasin, the unregulated Nautley River is selected for the streamflow calibration and subsequent analyses. Runoff attenuation due to the dam in the Nechako River is considered by calibrating VIC input parameters with monthly mean flows at the hydrometric gauging station at Hope, BC, the most downstream location on the Fraser River main stem covering the entire study period. By minimizing the difference between observed and simulated runoff at the outlet station, the diverted water to the Pacific Ocean from the Nechako River, which is the northwest part basin, is accounted for in the simulated hydrographs at the outlet. Even though the effect of the interbasin diversion in the Nechako is not completely removed, the streamflow estimation of the outlet of the FRB satisfies the goal of determining the contribution of snowmelt to 


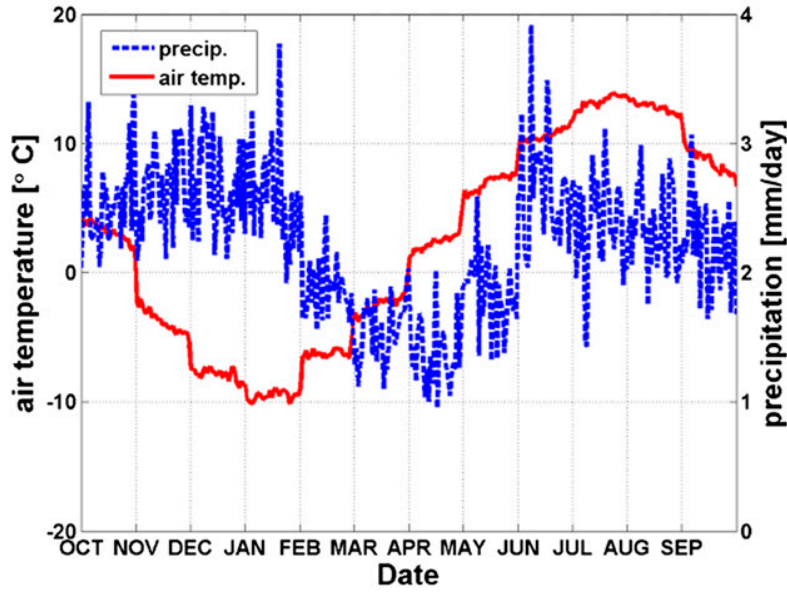

(a)

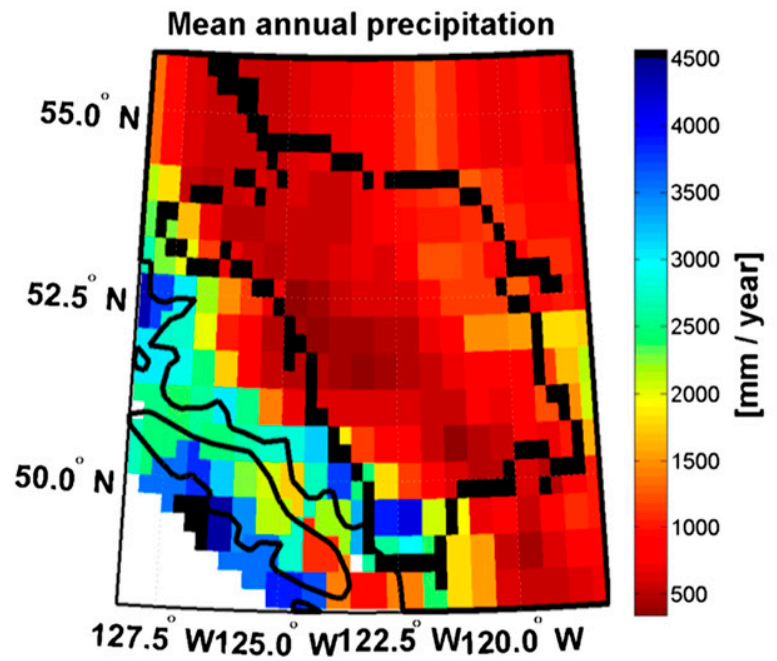

(c)

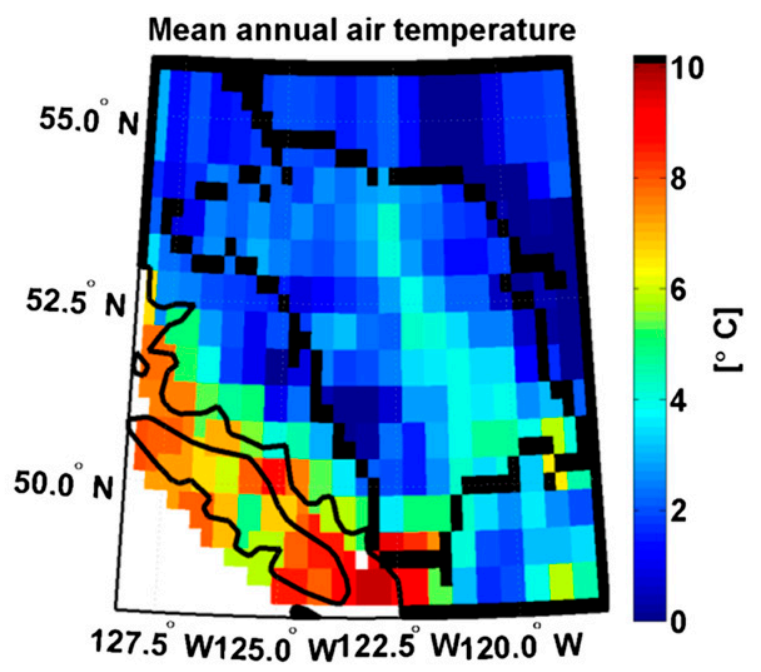

(b)

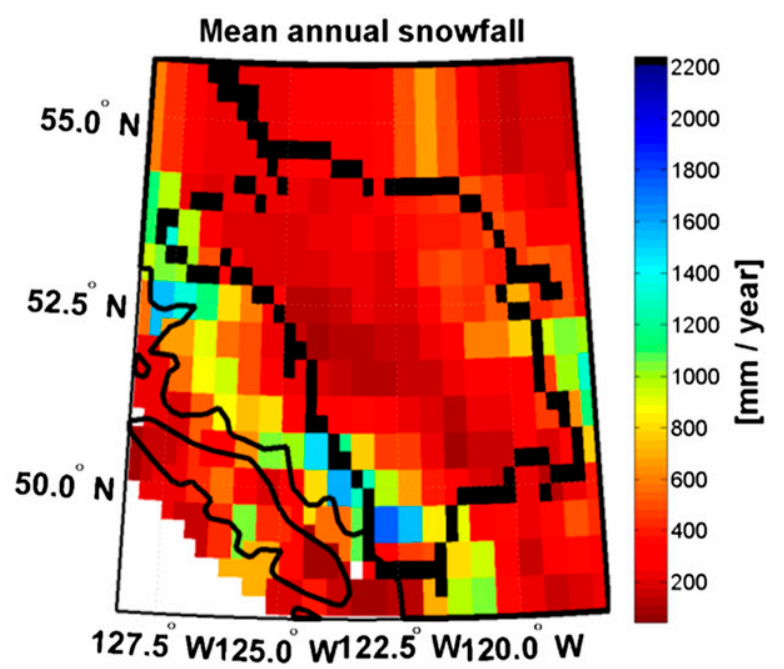

(d)

FIG. 2. (a) Annual cycle of mean daily air temperature and precipitation spatially averaged across the FRB. Spatial distribution across the FRB of mean annual (b) air temperature, (c) total precipitation, and (d) total snowfall, 1949-2006.

runoff generation for the entire FRB. The exclusion of the reservoir effect can be supported by the fact that the area upstream of the Kenney Dam within the Nechako River basin only occupies $6.5 \%$ of the FRB area. In addition, the fraction of the diverted water to the total annual runoff at Hope, BC amounts to only about $3 \%$ of the overall Fraser River at Hope, BC (Water Survey of Canada 2014; Déry et al. 2012). Across the FRB, outlets for the 11 gauged subwatersheds are selected to estimate the routed streamflow from the VIC simulations. Finally, the routing network is adopted from Wu et al. (2011). While the FRB is a typical cold region watershed, the "frozen soil" option is turned off in the VIC simulations. Since the FRB is mostly covered by a deep snowpack throughout the winter season, the underlying soil/ground is well insulated and maintains temperatures near or above $0^{\circ} \mathrm{C}$.

\section{b. Forcing dataset}

In this study, the VIC model is driven by daily precipitation, maximum air temperature (Tmax), minimum air temperature (Tmin), and average wind speed from 1948 to 2006 at a $0.25^{\circ}$ horizontal resolution. The forcing 


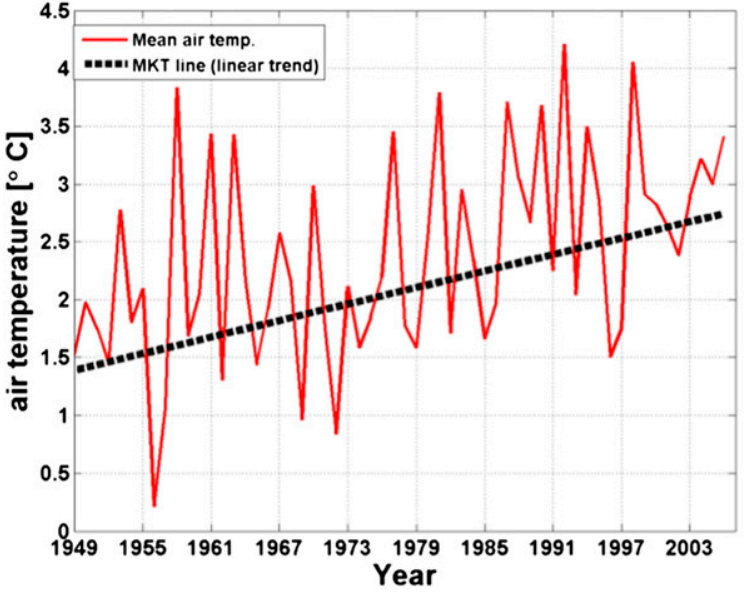

(a)

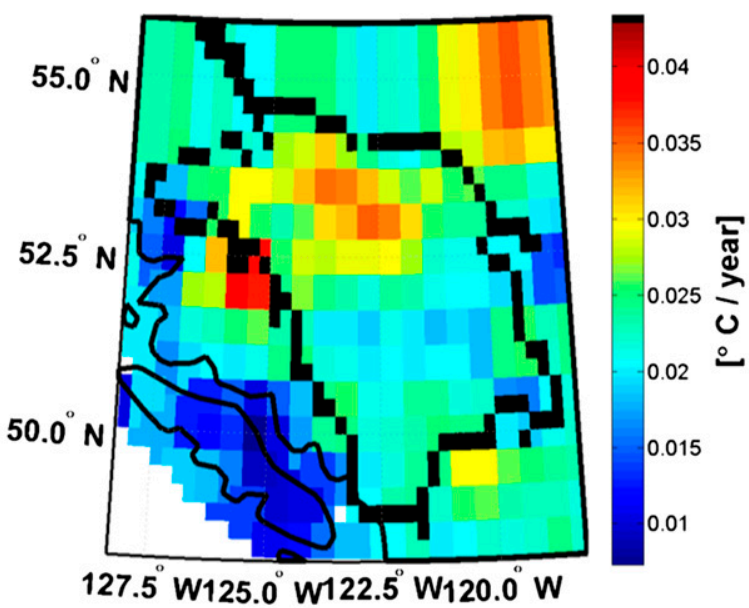

(c)

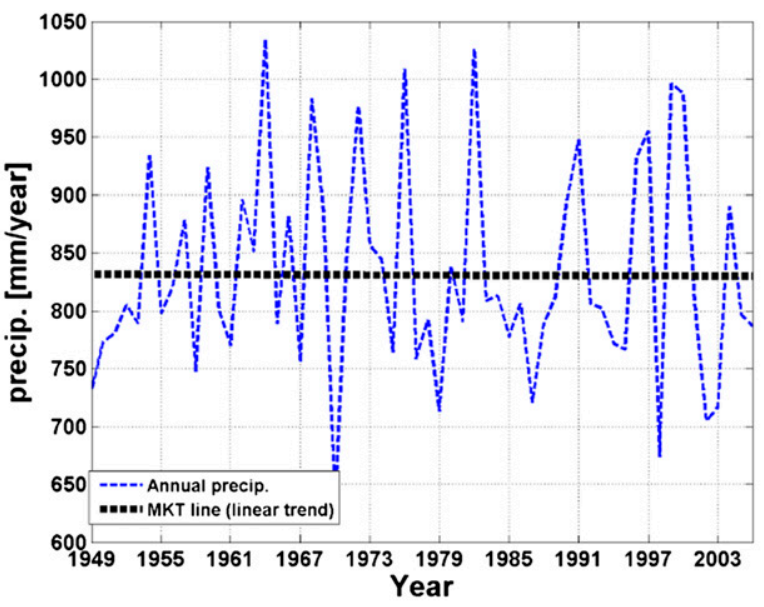

(b)

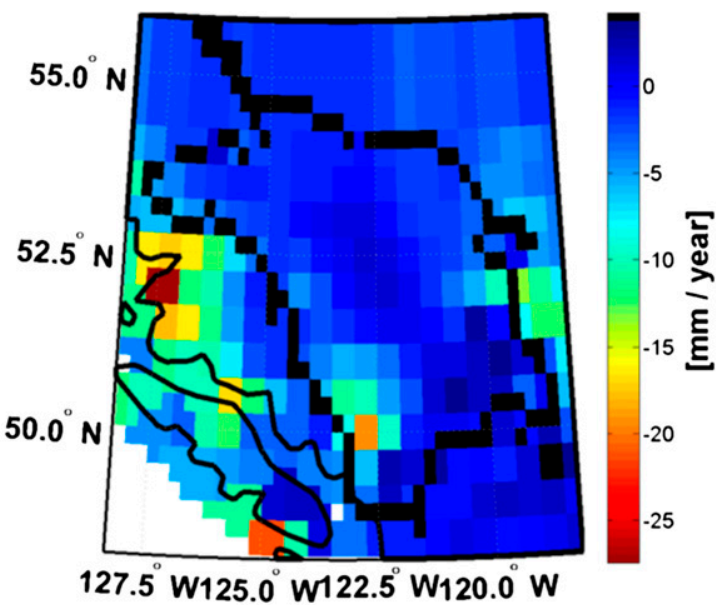

(d)

FIG. 3. Time series and linear trend (Mann-Kendall test trend line) of spatially averaged (a) mean annual air temperature and (b) total annual precipitation across the FRB, 1949-2006. Linear trends in grid-scale (c) annual air temperature and (d) annual precipitation across the FRB, 1949-2006.

dataset for the VIC model is sourced from the extended University of Washington gridded dataset (Shi et al. 2013; Adam et al. 2006; Adam and Lettenmaier 2008). Monthly precipitation originates from the University of
Delaware (UDel) observed land surface precipitation product (Matsuura and Willmott 2009). The UDel product is adjusted to account for gauge undercatch since solid precipitation is typically underestimated in

TABLE 2. Ranges and final values of VIC calibration parameters at Hope, BC.

\begin{tabular}{|c|c|c|c|c|}
\hline Name & Unit & Definition & Range & Final values \\
\hline b_infilt & - & Parameter used to describe the VIC & $0.00001-0.2$ & 0.112 \\
\hline Ds & - & Fraction of the Dsmax parameter at which nonlinear base flow occurs & $0.00001-0.1$ & 0.067 \\
\hline Ws & - & Fraction of maximum soil moisture where nonlinear base flow occurs & $0.2-0.6$ & 0.248 \\
\hline D2 & $\mathrm{m}$ & Depth of second soil layer & $0.7-1.0$ & 0.898 \\
\hline D3 & $\mathrm{m}$ & Depth of third soil layer & $0.7-2.5$ & 2.021 \\
\hline Dsmax & $\mathrm{mm}_{\text {day }}{ }^{-1}$ & Maximum velocity of base flow for each grid cell & $12.0-18.0$ & 13.971 \\
\hline
\end{tabular}


winter by $10 \%-50 \%$ (Adam and Lettenmaier 2003; Adam et al. 2006; Adam and Lettenmaier 2008; Shi et al. 2013). Monthly precipitation data are transformed to daily data using the high temporal precipitation dataset from Sheffield et al. (2006). Owing to a discontinuity and sharp decline in precipitation beginning in 2000 (based on the original forcing datasets), precipitation data onward are multiplied by a factor of 1.3. This step change in precipitation across the FRB is not observed in other datasets we examined, including the North American Regional Reanalysis (NARR; Mesinger et al. 2006) and in Environment Canada station-based records (Sanderson et al. 2014, manuscript submitted to Can. Geogr.; Environment Canada 2014). The factor of 1.3 is the ratio of the historical (1949-99) mean annual precipitation across the FRB relative to the 2000s.

Daily wind speeds are extracted from National Centers for Environmental Prediction-National Center for Atmospheric Research (NCEP-NCAR) reanalysis datasets (Kalnay et al. 1996). These four forcing variables (i.e., daily precipitation, daily Tmax, daily Tmin, and daily average wind speed) are used to drive the VIC simulations from 1 January 1948 to 31 December 2006 in the FRB. A model spinup time is considered with 10 years from the beginning of the simulation; thus, the state file for 1958 is used to initialize the VIC model.

To evaluate the FRB's climate from 1949 to 2006 water years, the forcing dataset for the VIC simulation is analyzed. First, forcing datasets for air temperatures (using the mean of daily Tmin and Tmax) and precipitation are averaged across the watershed during the water year. An average daily air temperature across the FRB is superimposed with a spatially averaged precipitation during the water year (Fig. 2a). The air temperature remains below $0^{\circ} \mathrm{C}$ from November to April. In May and June, the air temperature climbs above $0^{\circ} \mathrm{C}$ to reach $10^{\circ} \mathrm{C}$, thus inducing snowmelt across the basin. Snowfall begins in November and persists until April in a given water year.

Figure $2 \mathrm{~b}$ shows the spatial distribution of mean air temperature in the FRB in water years from 1949 to 2006 at the resolution of the VIC model application. While coastal areas are the mildest in $\mathrm{BC}$, the interior portions of the FRB have noticeably warmer air temperatures compared to the high-elevation Coast and Rocky Mountains. Note also that the middle Fraser in the interior plateau (see in Figs. 1a and 2c) is the driest section in the FRB, while snowfall is predominant in the Coast and Rocky Mountains (Fig. 2d). Therefore, the limited amounts of precipitation in the upper/middle Fraser and Thompson River basins are sustained by upstream mountain snowpacks deposited during winter.
In addition to the spatial distribution of averaged air temperature and precipitation, their trends over 58 years are also shown in Figs. $3 \mathrm{a}$ and $3 \mathrm{~b}$. This shows warming of $1.4^{\circ} \mathrm{C}$ over 58 years across the entire FRB (Fig. 3a) during the latter part of the twentieth century. On the other hand, precipitation does not change over the same period (Fig. 3b). Since these linear trends represent spatially averaged values across the FRB, trends in air temperature and precipitation are also assessed at the gridpoint scale (Figs. 3c,d). According to the spatial distribution of the air temperature trends, the northernmost Upper Fraser and Nechako subwatersheds experienced relatively stronger warming rates of $0.4^{\circ} \mathrm{Cdecade}^{-1}$, and other FRB areas had increasing air temperature trends of $0.2^{\circ} \mathrm{C}_{\text {decade }}{ }^{-1}$. In addition, there is no significant change in precipitation over 58 years across the FRB (Fig. 3d).

\section{c. Parameter calibration in VIC}

VIC simulations from 1948 to 1968 are used for model calibration. This optimization process is conducted by minimizing the difference between observed and simulated monthly streamflow at Hope, BC, using the Nash-Sutcliffe efficiency (NSE) coefficient (Nash and Sutcliffe 1970). The gauge station at Hope, BC, which covers $97 \%$ of the FRB drainage area, has a continuous streamflow record from 1912 to 2006 (end year of the simulations). To further investigate the spatial variations of hydrological responses, the FRB is divided into 11 subwatersheds to evaluate the VIC model's performances of SWE, $R$, and their ratio, $R_{\mathrm{SR}}$, from 1949 to 2006. The calibration is applied to all 11 subwatersheds to determine the most optimized parameters against the observed streamflow at each basin.

The University of Arizona multiobjective complex evolution (MOCOM-UA) optimizer is selected for the calibration process (Yapo et al. 1998; Shi et al. 2008). MOCOM-UA searches a set of VIC input parameters using the population method to maximize the NSE coefficient between observed and simulated runoff. At each trial by iterative MOCOM-UA processes, the multiobjective vector consisting of VIC parameters is determined and then the population is ranked by the Pareto rank of Goldberg (1989). Here, the training parameter set used in the optimization process is composed of six variables in the soil dataset: $b \_$infilt (a parameter of the variable infiltration curve), Dsmax (the maximum velocity of base flow for each grid cell), Ws (the fraction of maximum soil moisture where nonlinear base flow occurs), D2 and D3 (the depths of the second and third soil layers), and Ds (the fraction of the Dsmax parameter at which nonlinear base flow occurs).

By minimizing the difference between the simulated and corresponding observed monthly runoff, these six VIC parameters are optimized. The definitions, ranges, 
TABLE 3. NSE coefficients during the calibration and validation periods in VIC simulations for the FRB.

\begin{tabular}{cll}
\hline \hline Watershed & \multicolumn{1}{c}{$\begin{array}{c}\text { NSE (1948-68): } \\
\text { Monthly (daily) }\end{array}$} & $\begin{array}{c}\text { NSE (1969-2006): } \\
\text { Monthly (daily) }\end{array}$ \\
\hline SU & $0.54(0.51)$ & $0.37(0.37)$ \\
NA & $0.80(0.76)(1950-68)$ & $0.55(0.54)$ \\
UF & $0.79(0.70)(1950-68)$ & $0.73(0.65)$ \\
QU & $0.78(0.62)$ & $0.79(0.69)$ \\
CH & $0.68(0.68)$ & $0.38(0.38)$ \\
NT & $0.87(0.80)(1957-68)$ & $0.78(0.71)$ \\
ST & $0.87(0.79)$ & $0.79(0.71)$ \\
TN & $0.90(0.83)$ & $0.86(0.78)$ \\
LF1 & $0.93(0.86)$ & $0.85(0.79)$ \\
LH & $0.61(0.15)(1951-68)$ & $0.59(0.14)$ \\
LF2 & $0.92(0.85)(1965-68)$ & $0.87(0.77)(1968-92)$ \\
\hline
\end{tabular}

and final values of these calibrated parameters used for the case of the station at Hope, BC are listed in Table 2. All 11 subbasins are used to determine the parameters using the MOCOM-UA method. Monthly and daily NSE values between simulated and observed runoff during both the calibration (1948-68) and validation (1969-2006) periods are also provided in Table 3. Here, the interbasin diversion effect in the Nechako River is statistically considered after the calibration processes to linearly reduce the amount of runoff at the outlet station of the main stem of the Fraser River in Hope, BC, by artificially reducing the streamflow owing to the amount of diverted water of the Nechako River. This is because the outlet includes influx from the Nechako River even after the impoundments.

\section{d. Observed streamflow and SWE}

To calibrate and validate the simulated runoff by the VIC model, daily streamflow data from Environment Canada's Hydrometric Dataset (HYDAT; Water Survey of Canada 2014) are used. Déry et al. (2012) extracted and compiled a comprehensive streamflow dataset for the FRB spanning 1911-2010. The selected stations here cover the major subbasins of the FRB: Stuart River (SU), Nautley River (NA), upper Fraser River (UF), Quesnel River (QU), Chilko River (CH), North Thompson River (NT), South Thompson River (ST), Thompson-Nicola River (TN), lower Fraser River at Hope (LF1), Lillooet-Harrison River
(LH), and lower Fraser River at Mission (LF2). Table 1 summarizes the hydrometric gauges, their coordinates, basin characteristics, and data availability, and Fig. 1a shows the location of these 11 gauge stations across the FRB. Typically, the most downstream hydrometric station in each subbasin is selected, with the exception of the NA, the largest one among unregulated tributaries within the highly regulated Nechako watershed.

In addition, the simulated SWE is also compared with an observational dataset from the BC River Forecast Centre's network of snow pillow sites (BC Ministry of Forests Lands and Natural Resource Operations 2014). The snow pillow stations record the weight of the accumulated snowpack (SWE) on a daily basis. There are 51 snow pillow stations currently in operation across $\mathrm{BC}$, but only a few have long-term, historical ( $>20 \mathrm{yr}$ ) records in the FRB. SWE observations from four sites located in the middle to upper Fraser are thus selected to evaluate the SWE simulations by the VIC model. The locations of the four stations are shown in Fig. 1a and are summarized in Table 4, with their names, locations, elevations, station identifications, and data availability.

\section{Methods}

\section{a. Snow contribution to runoff generation}

To quantify the contribution of snow to runoff generation across the basin, $R_{\mathrm{SR}}$ each water year is obtained from (Déry et al. 2005a)

$$
R_{\mathrm{SR}}=\mathrm{SWE}_{\text {melt }} / \sum_{t=1}^{N} R_{t},
$$

where $R$ is the runoff $\left(\mathrm{mm} \mathrm{day}^{-1}\right)$ and $N$ is 365 or 366 , depending on whether a given year is a leap year or not, noting that $t=1$ marks 1 October of a given water year. The $\mathrm{SWE}_{\text {melt }}$ is defined by

$$
\mathrm{SWE}_{\text {melt }}=\mathrm{SWE}_{\text {max }}-\mathrm{SWE}_{\text {min }} \text {, }
$$

where $\mathrm{SWE}_{\max }$ is $\max \left\{\mathrm{SWE}_{t}\right\}_{t=1, \ldots, N}$, and $\mathrm{SWE}_{\min }$ is $\min \left\{\mathrm{SWE}_{t}\right\}_{t=1, \ldots, N}$.

The simulated streamflow is converted to areal runoff by dividing it by the corresponding watershed area.

TABLE 4. Description of selected snow pillow stations used for SWE comparisons against VIC simulations using the NSE coefficients.

\begin{tabular}{cclcccccc}
\hline \hline No. & Basin & \multicolumn{1}{c}{ Station name } & Elev $(\mathrm{m})$ & Lat $\left({ }^{\circ} \mathrm{N}\right)$ & Lon $\left({ }^{\circ} \mathrm{W}\right)$ & Record length & Status & NSE \\
\hline 1A01P & Upper Fraser & Yellowhead & 1860.0 & 52.90 & 118.63 & 1996 -present & Active & 0.68 \\
1A02P & Upper Fraser & McBride (Upper) & 1620.0 & 53.30 & 120.33 & $1971-86$ & Active & 0.74 \\
& & & & & & 2006 -present & & \\
$1 \mathrm{C} 18 \mathrm{P}$ & Middle Fraser & Mission Ridge & 1850.0 & 50.77 & 122.20 & 1969 -present & Active & 0.71 \\
$1 \mathrm{C} 20 \mathrm{P}$ & Middle Fraser & Boss Mountain Mine & 1460.0 & 52.12 & 120.87 & 1993 -present & Active & 0.70 \\
\hline
\end{tabular}



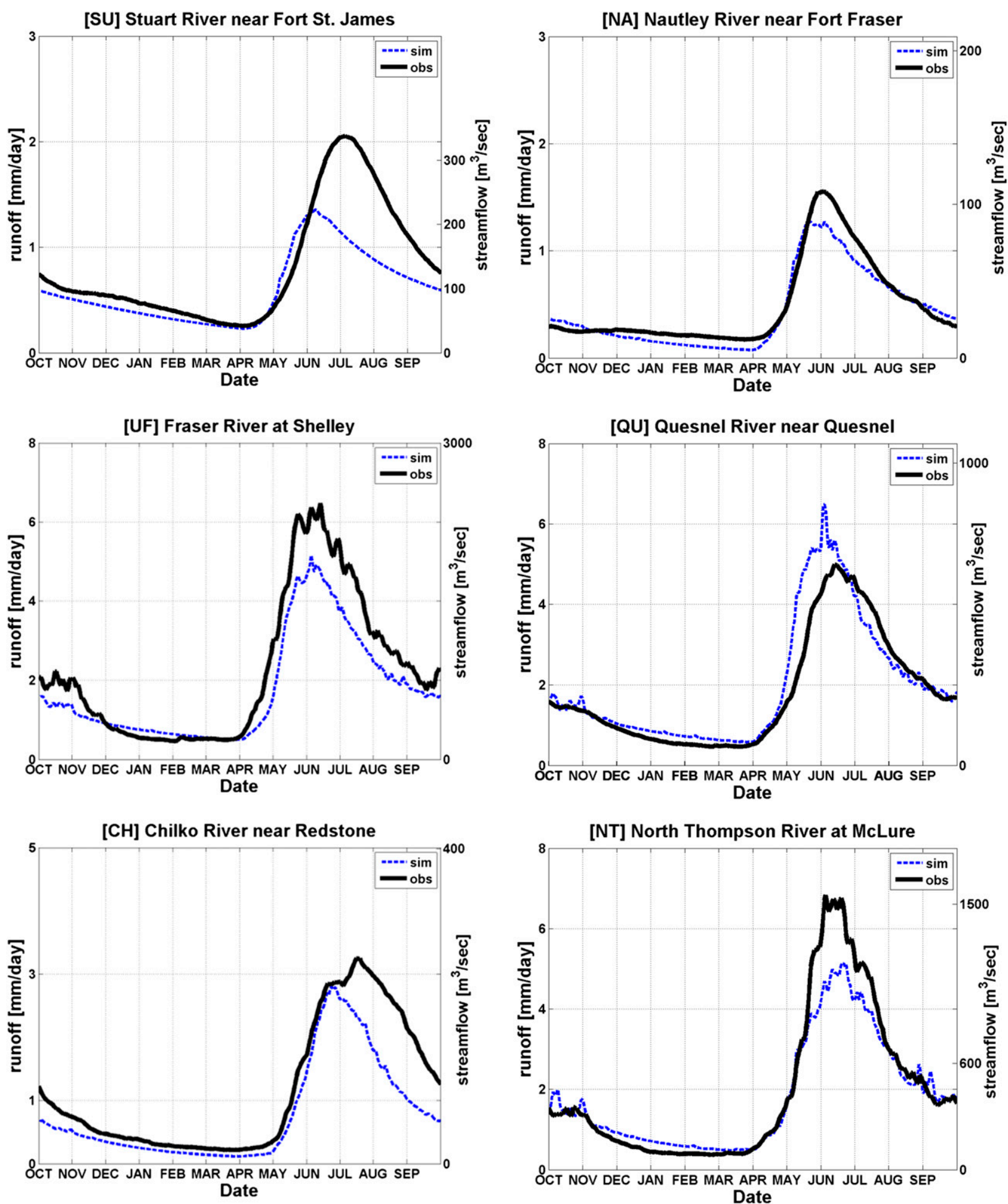

FIG. 4. Simulated (sim) and observed (obs) runoff for the Fraser River and its major subwatersheds for the calibration period (1948-68).

Daily runoff at the outlet cell corresponding to the streamflow station over a given water year is temporally integrated to obtain a total annual runoff at a selected basin. Note that $R_{\mathrm{SR}}$ is computed with the runoff after the routing of the streamflow, except when examined at the grid scale, and that another $R_{\mathrm{SR}}$ is also determined using the observed $R$ instead of the simulated $R$ with the same SWE $\mathrm{E}_{\text {melt }}$. 

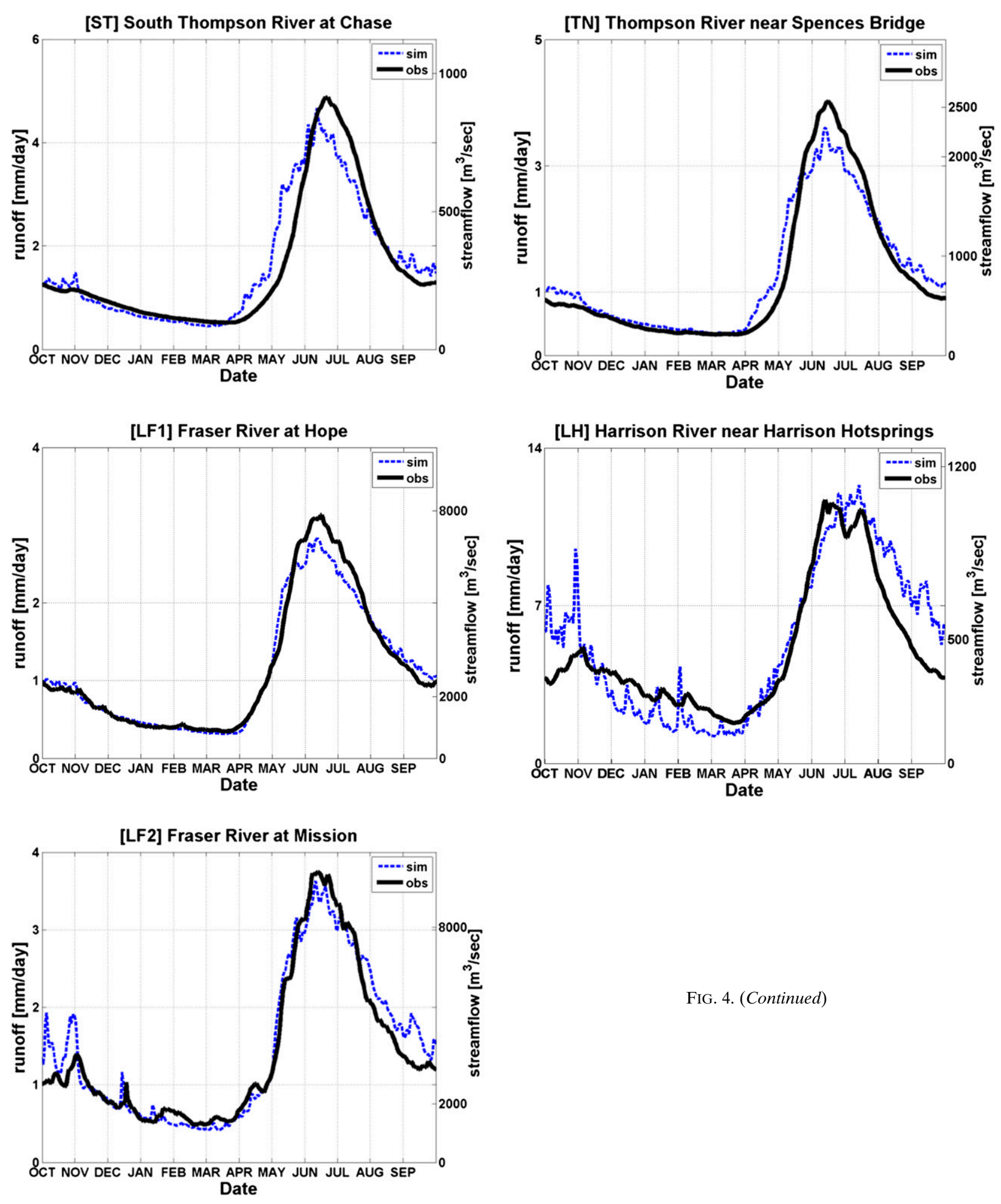

FIG. 4. (Continued)

\section{b. Hydrologic sensitivity under perturbed air temperature and precipitation}

To evaluate the possible impacts of climate change on the hydrology of the FRB, the air temperature and precipitation values in the forcing dataset are perturbed to perform a series of sensitivity tests. Here, Tmin and Tmax are perturbed by $\pm 1.0^{\circ} \mathrm{C}$ and $\pm 2.0^{\circ} \mathrm{C}$, whereas precipitation is multiplied by factors of 0.9 and 1.1 to explore impacts to the simulated 
[SU] Stuart River near Fort St. James

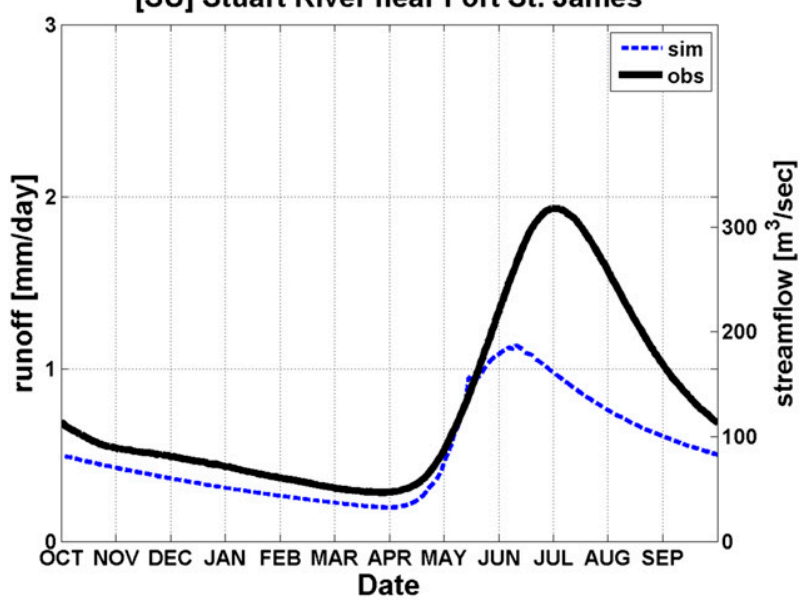

[UF] Fraser River at Shelley

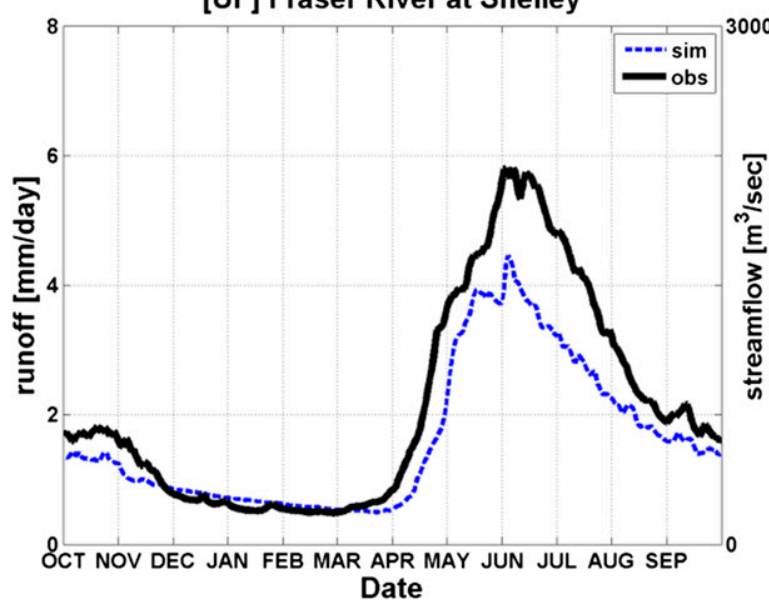

[CH] Chilko River near Redstone

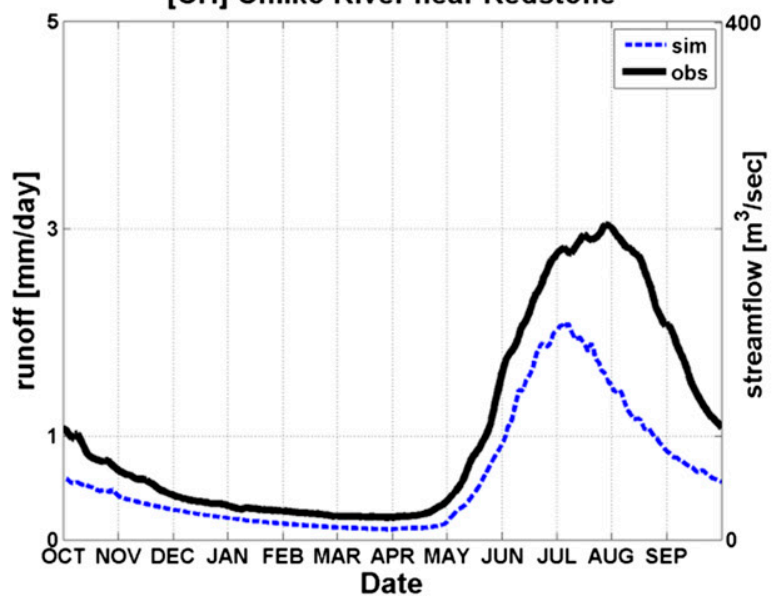

[NA] Nautley River near Fort Fraser

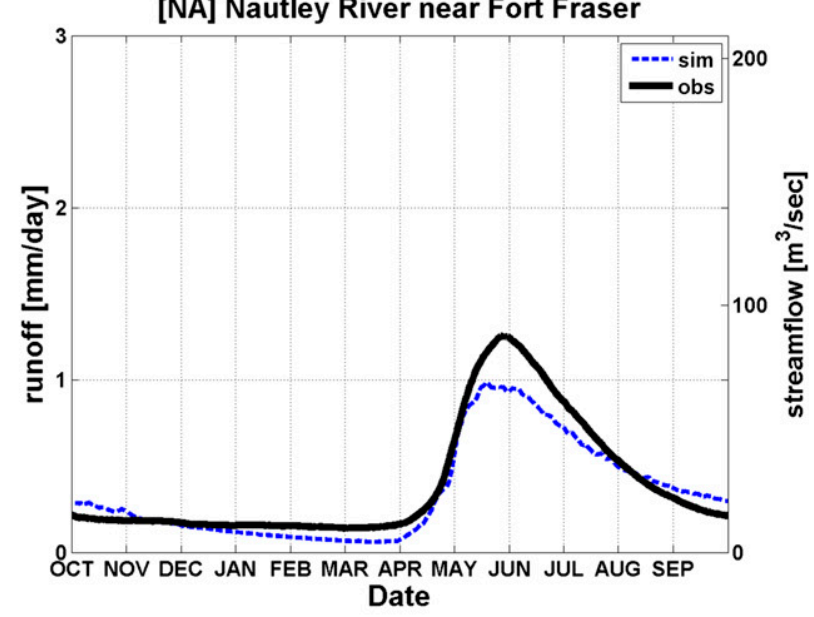

[QU] Quesnel River near Quesnel

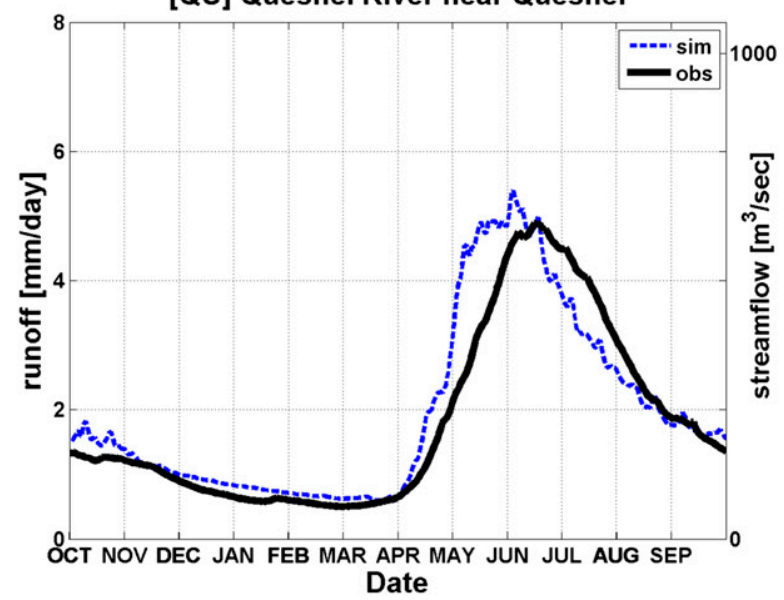

[NT] North Thompson River at McLure

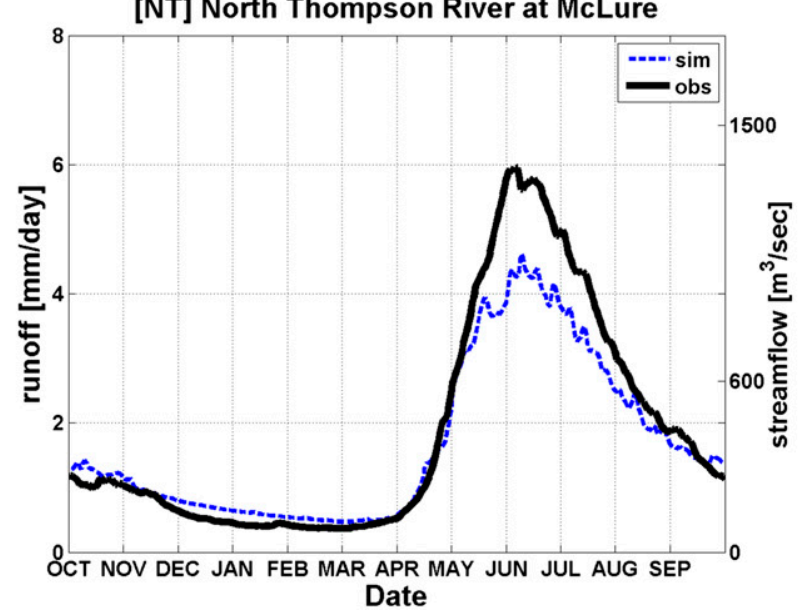

FIG. 5. As in Fig. 4, but for the validation period (1969-2006).

SWE and runoff. This approach follows Vano et al. (2012), who evaluated the sensitivity and the elasticity of hydrologic responses as simulated by multiple hydrological models including VIC over the Colorado River basin of the United
States. In addition to the separate perturbations, the simultaneous changes in the air temperature and precipitation are also applied to the VIC simulations to determine a dominant factor in the snowmelt contribution to the runoff. 

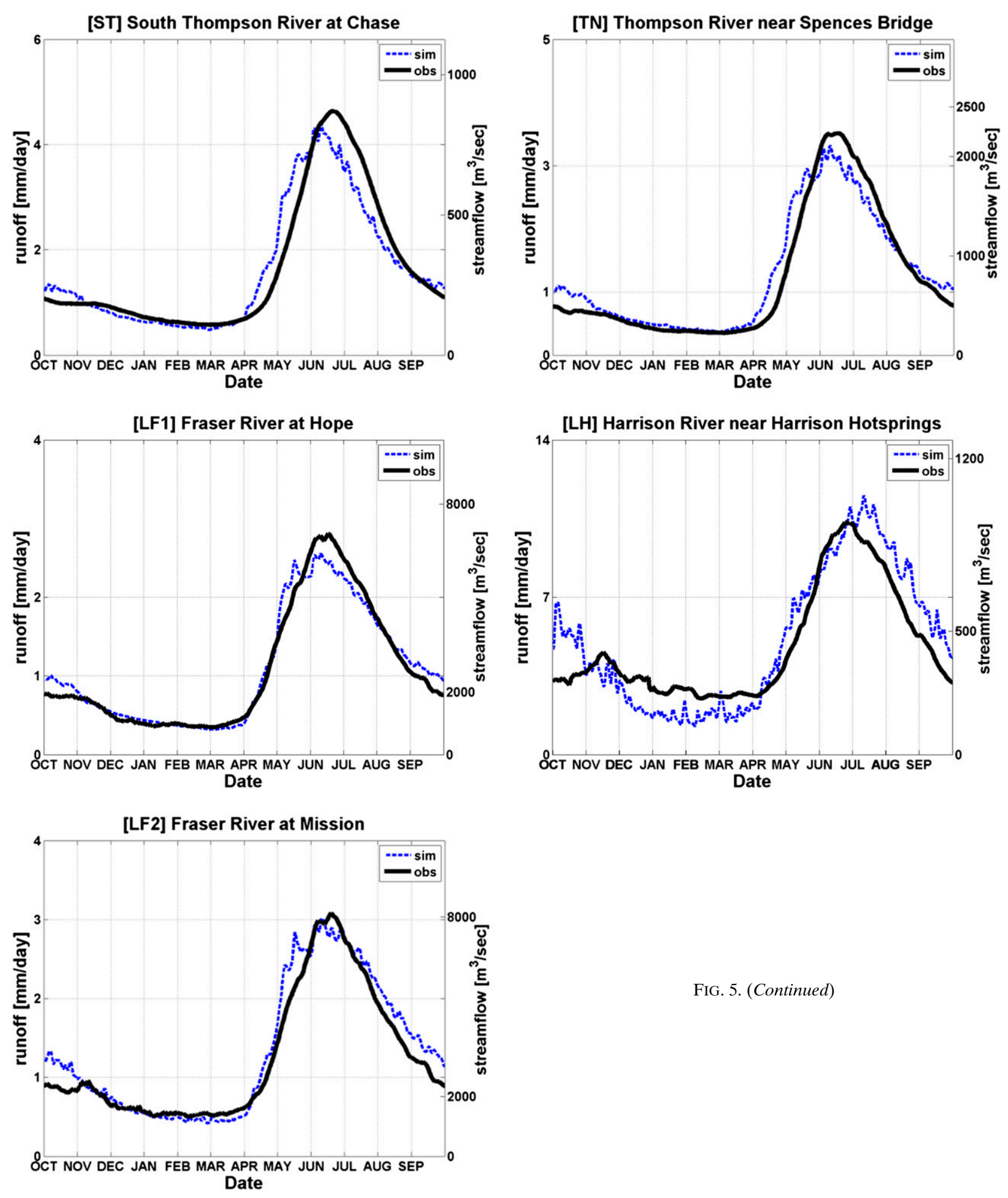

FIG. 5. (Continued)

\section{c. Mann-Kendall statistics}

Using the Mann-Kendall test statistics (Mann 1945, Kendall 1970; Déry et al. 2005b), temporal trends of $R_{\mathrm{SR}}$ and other hydrometeorological variables are evaluated

in all 11 subwatersheds. To reject the null hypothesis that there is no trend, the $p$ value of the Mann-Kendall test needs to be lower than a given value, here chosen as $p<0.05$. 


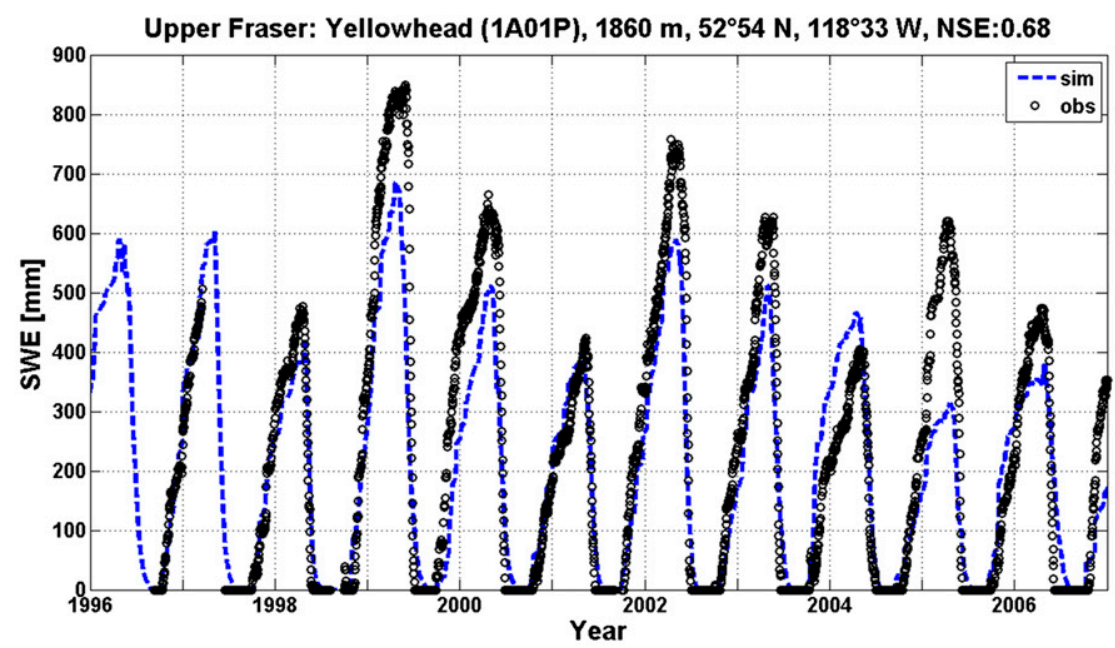

(a)

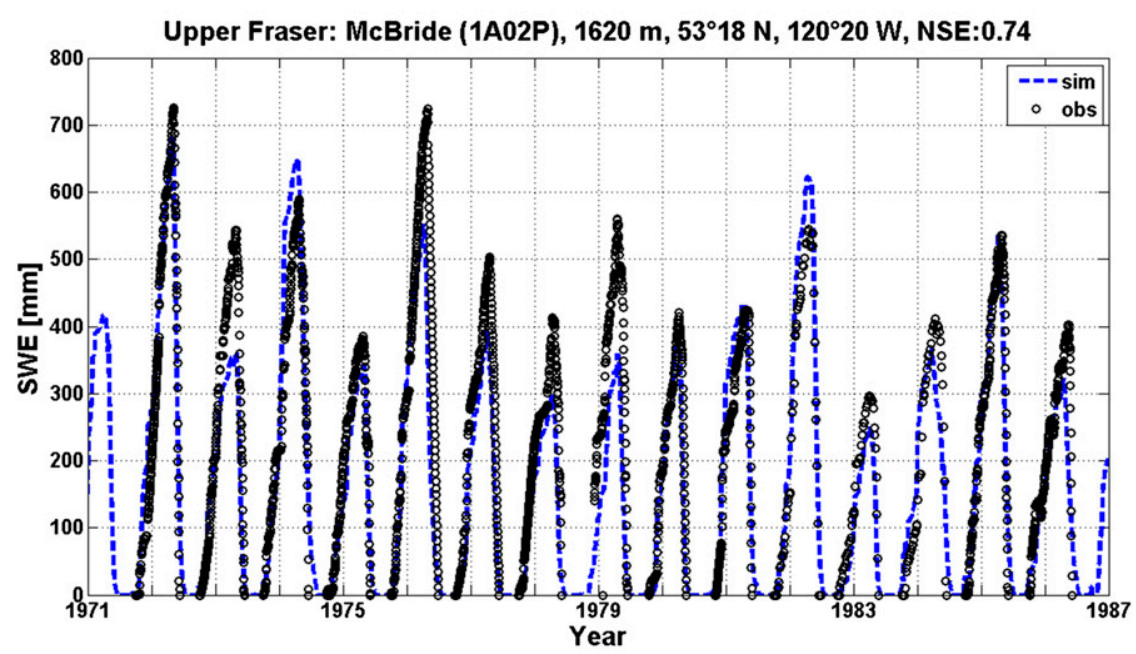

(b)

FIG. 6. Validation of daily SWE simulations using BC snow pillow daily observations in the upper Fraser at (a) Yellowhead (1A01P) and (b) McBride (1A02P) and middle Fraser at (c) Mission Ridge (1C18P) and (d) Boss Mountain Mine (1C20P).

\section{Results and discussion}

\section{a. Runoff: Calibration and validation}

Fig. 4 compares the calibrated and observed runoff at the 11 gauged subwatersheds. The amount of low flow and timing of the runoff peaks are better captured as the basin areas increase, for example, from the North Thompson, South Thompson, Thompson-Nicola, Fraser at Hope, and Fraser at Mission. The upper (Fraser River at Shelley) and middle (Quesnel River) Fraser also show relatively good fits with the observations (Table 3). However, the hydrology of the Stuart River subwatershed is not well represented with respect to the peak timing, while the amount of low flows is properly simulated in the calibration period. The Chilko River also shows a reasonable amount of low flows and timing compared with observations during the calibration period, except for the amount of peak flow in July and August.

After the calibration process, the model outputs are then validated for the period from 1969 to 2006 in the 11 subwatersheds of interest (Fig. 5). The observed runoff peak induced by snowmelt in May and June is well captured by the VIC simulations at Hope, BC, and other major tributaries (Fig. 5, Table 3). Overall, the comparisons show NSE coefficients $>0.6$ both in the calibration and validation periods, except for the Stuart, Nautley, and Chilko Rivers with an NSE $<0.6$ in the validation period. Note that the upstream portion of the Chilko basin includes Chilko Lake, one of the largest mountain lakes in the Coast Mountains, which affects the hydrograph at 


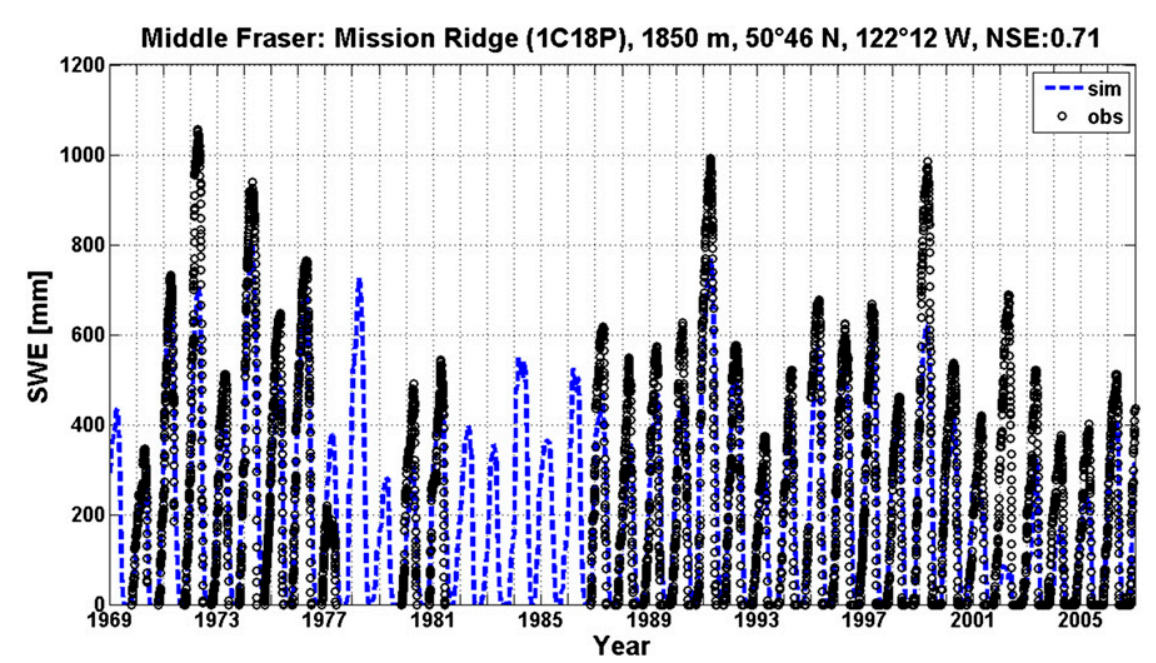

(c)

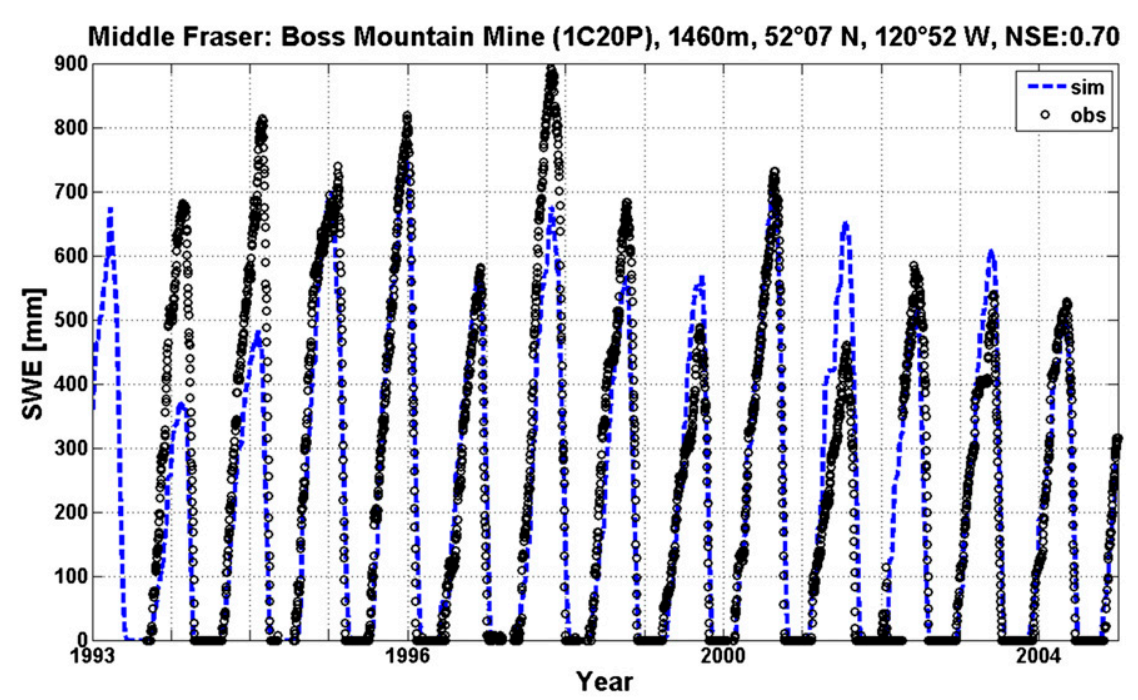

(d)

FIG. 6. (Continued)

Redstone, BC. In the Stuart River, the hydrometric gauge is located in the far northern part of the FRB at the outlet to Stuart Lake, which also attenuates observed hydrologic signals not captured by the VIC model. The daily comparison for the coastal Lillooet-Harrison River also shows a relatively low NSE score, perhaps attributed to the multiple runoff-generating processes in this watershed that include glacier melt in the Coast Mountains, high-elevation snowpacks, and abundant rainfall at lower elevations.

Even with variations in hydrologic responses across the FRB, the NSE values at the hydrometric station at Hope, BC, are 0.93 and 0.85 for the calibration and validation periods, respectively. The timing of peak flows induced by snowmelt is well simulated in June and
July. Considering the main objective of this paper is to evaluate the contribution of snowmelt to the runoff in the entire FRB, the satisfactory NSE statistics at the outlet provide confidence the VIC model can be applied to the FRB to obtain accurate simulations of its hydrologic responses to climate forcing.

\section{b. SWE and $\mathrm{SWE}_{\mathrm{melt}}$}

There is a spatial discrepancy between the simulated $\left(0.25^{\circ}\right)$ and observed (single point) SWE that may lead to an uncertainty in snow estimations by models or remote sensing (Elder et al. 1991; Tong et al. 2010). In addition to the scale issues, the SWE time series are often discontinuous; nonetheless, relatively long periods (up to $20 \mathrm{yr}$ ) for validations are possible between BC 


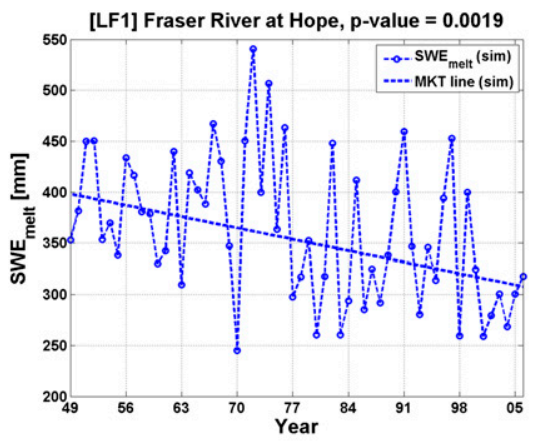

(a)

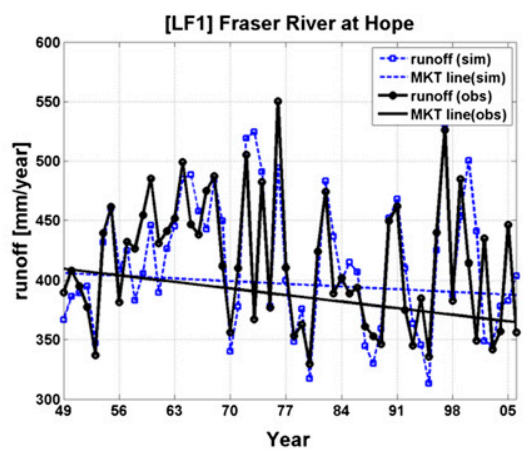

(b)

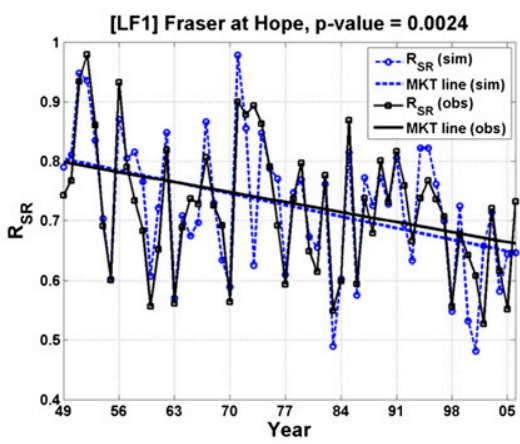

(c)

FIG. 7. Time series and linear trends of simulated annual (a) $\mathrm{SWE}_{\text {melt }}$, (b) $R$, and (c) $R_{\mathrm{SR}}$ over the hydrological year spatially averaged across the FRB upstream of Hope, BC, 1949-2006.

snow pillow sites and the VIC simulated SWE. Some of the SWE simulations, especially in the upper and middle Fraser where a high volume of SWE is deposited, are compared with the observed SWE (BC Ministry of Forests Lands and Natural Resource Operations 2014). For example, the VIC model simulations of SWE compare favorably to the daily observations at Mission Ridge in the middle Fraser over a 30-year period $(\mathrm{NSE}=0.71$; Table 3 ). In fact, all simulated time series of SWE have NSE values $>0.65$ in the upper and middle Fraser areas, demonstrating that the VIC model is able to capture the interannual variability in snow accumulation (Fig. 6; also see Fig. 1a for the snow stations used here). In contrast, the observed SWE values in the lower Fraser are not well captured by VIC, perhaps owing to its coastal influence and strong sensitivity to air temperatures (not shown). Nonetheless, this provides confidence that the VIC model is able to simulate SWE and $\mathrm{SWE}_{\text {melt }}$ across most of the FRB, and hence its overall contribution to streamflow generation for the FRB.

\section{c. $R_{\mathrm{SR}}$}

The ratio $R_{\mathrm{SR}}$ in Fig. 7c provides an estimate of the contribution of snow to the annual runoff within the FRB. There are decreasing trends both of simulated $\mathrm{SWE}_{\text {melt }}$ and $R$ for Figs. 7a and 7b, respectively, from 1949 to 2006 for the Fraser River at Hope, with slopes -1.72 and $-0.40 \mathrm{~mm} \mathrm{yr}^{-1}$, respectively. Using the observed $R$, another $R_{\mathrm{SR}}$ is also determined in Fig. 7c. It shows a lower decreasing trend than the simulated $R_{\mathrm{SR}}$. This results in a decline of $R_{\mathrm{SR}}$ from 0.80 to 0.65 over the study period. Computing $R_{\mathrm{SR}}$ using the observed runoff yields a trend very similar to that from the VIC simulations.

The $R_{\mathrm{SR}}$ for all subbasins of the FRB show statistically significant, decreasing trends, with the exception of the Nautley and Stuart Rivers (Fig. 8, Table 5). The trends decrease monotonically and become steeper when moving downstream along the Fraser River. There are statistically significant decreasing trends of SWE contribution to runoff generation in 9 of 11 FRB subwatersheds with reductions $>16 \%$, most notably in the downstream reaches of the FRB between 1949 and 2006 (ST, NT, TN, and LF1/LF2 shown in Table 5). Note the largest decrease $(26 \%)$ arises in the South Thompson River that drains parts of the Canadian Rockies. Figure 9a also shows grid-scale trends in $\mathrm{SWE}_{\text {melt }}$ across the FRB from 1949 to 2006 . The largest declines $(-200 \mathrm{~mm})$ are found in the lower Coast Mountains and the Canadian Rocky Mountains in the headwaters of the Fraser River (corresponding to the $\mathrm{LH}$ and UF/NT subbasins). The decline average $\mathrm{SWE}_{\text {melt }}$ across the FRB is $107 \mathrm{~mm}$ (from 444 to $337 \mathrm{~mm}$ in 1949 and 2006, respectively). The decrease of $R_{\mathrm{SR}}$ is thus mainly attributed to declines in snow accumulation rather than changes in runoff amounts, consistent with the overall lack of trend in precipitation across the FRB but a change in its phase.

\section{d. Spatial patterns of trends in $R_{\mathrm{SR}}$}

Spatial patterns of trends in $R_{\mathrm{SR}}$ are also evaluated across the FRB (Figs. 9b,c). Here, a gridded version of $R_{\mathrm{SR}}$ is determined by dividing the $\mathrm{SWE}_{\text {melt }}$ at each grid cell with the water year sum of runoff and base flow in the same cell determined by VIC. This spatial representation of $R_{\mathrm{SR}}$ effectively describes its spatiotemporal patterns across the FRB. Large $R_{\mathrm{SR}}$ values are found at high elevations across the FRB with a strong declining gradient to the interior plateau. Negative trends in $R_{\mathrm{SR}}$ are also dominant in the interior plateau surrounded by the Coast and Cariboo Mountains, just east of the Quesnel River subbasin. The significance of those gridscale trends are assessed with the Mann-Kendall test as well with binary numbers indicating 1 (trend, $p<0.05$ ) 
[SU] Stuart River near Fort St. James, p-value $=0.1436$

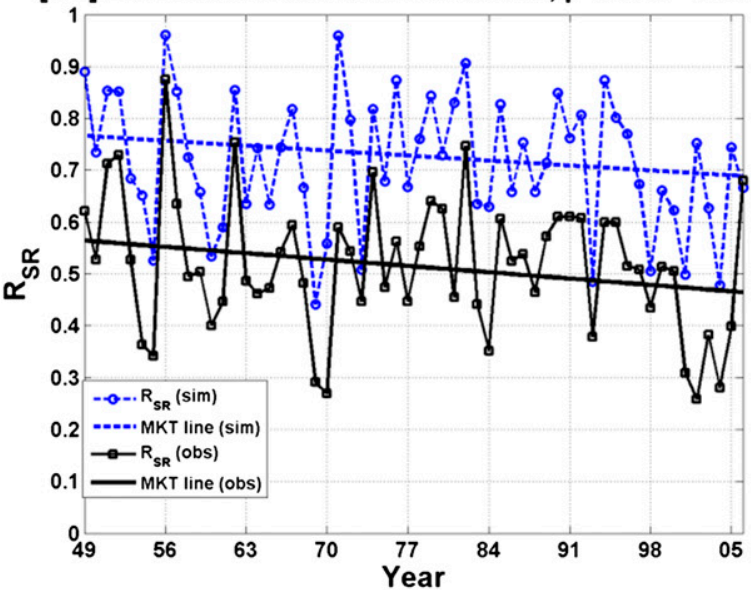

[UF] Fraser River at Shelley,p-value $=\mathbf{0 . 0 0 5 3}$

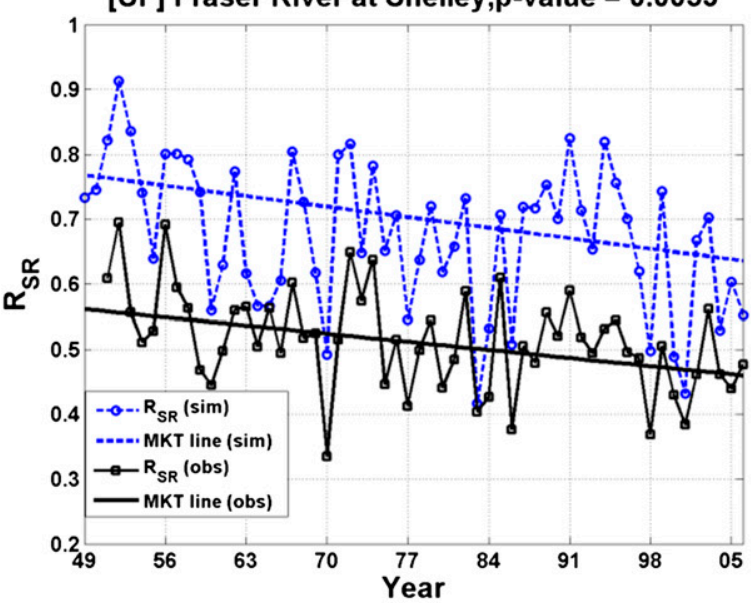

[CH] Chilko River near Redstone, $p$-value $=0.1104$

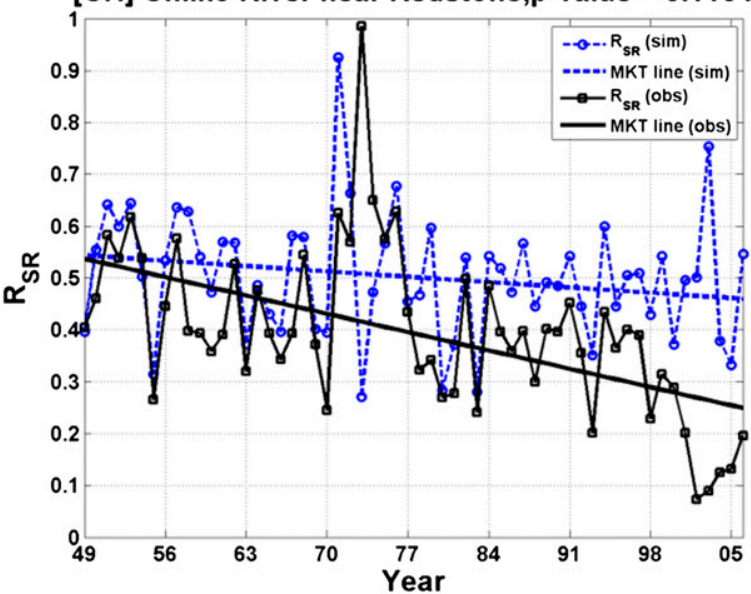

[NA] Nautley River near Fort Fraser, $p$-value $=\mathbf{0 . 0 9 8 9}$

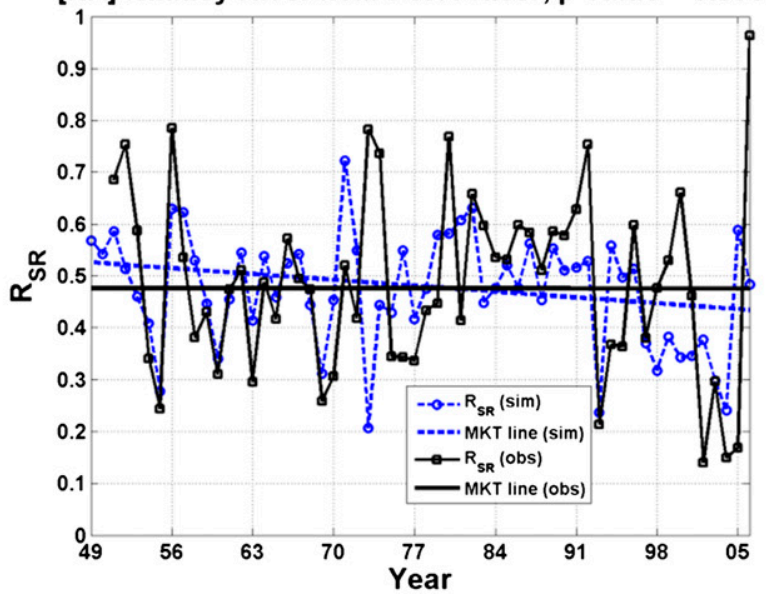

[QU] Quesnel River near Quesnel, p-value $=0.0108$

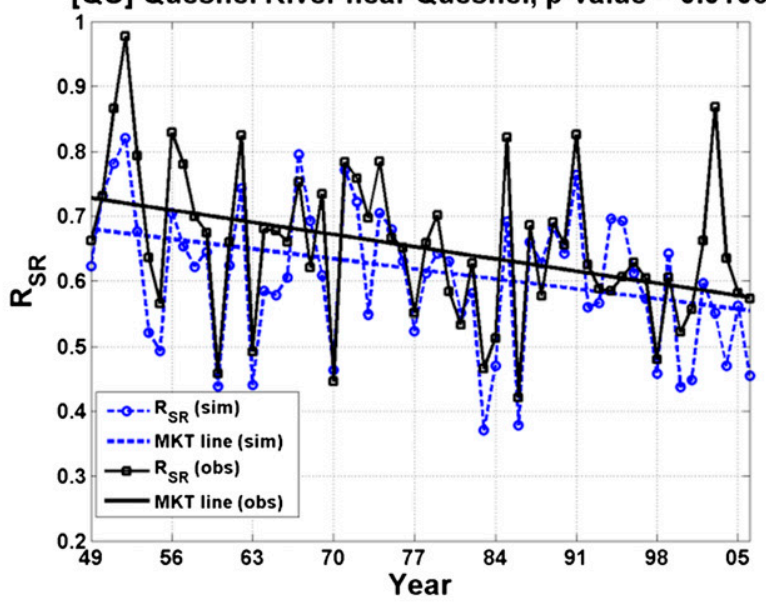

[NT] North Thompson River at McLure, $\mathrm{p}$-value $=\mathbf{0 . 0 1 0 8}$

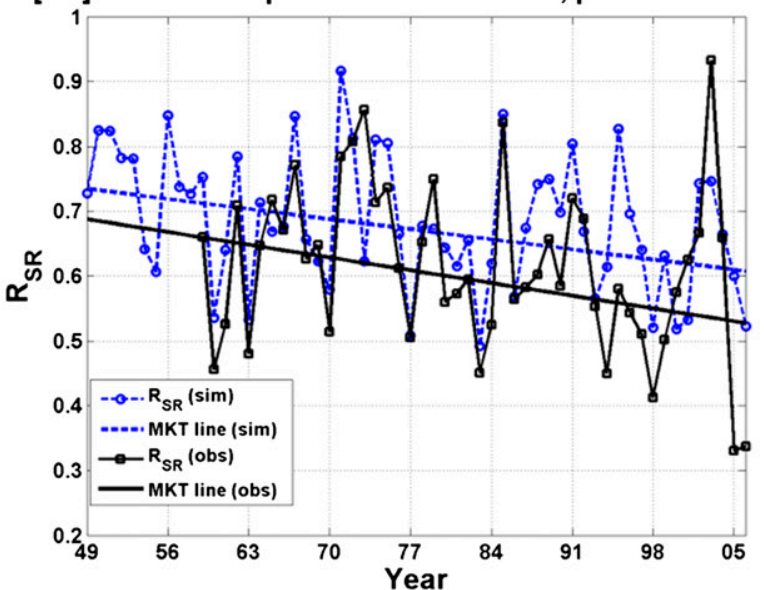

FIG. 8. Time series and linear trends of simulated annual ratio $R_{\mathrm{SR}}$ over the hydrological year spatially averaged across the Fraser River subbasins: SU, NA, UF, QU, CH, NT, ST, TN, LF1, LH, and LF2.

and 0 (no trend, $p \geq 0.05$; Fig. 9c). The Thompson-Nicola River in the southwestern part of the FRB is also found to have a decreasing trend in addition to the Chilko and upper Fraser watersheds. Note that not only the lower
Coast Mountains but also the Thompson-Nicola (windward of the Rocky Mountains) basin appear to have lower contributions of snow to the runoff generation during the latter part of the twentieth century. 


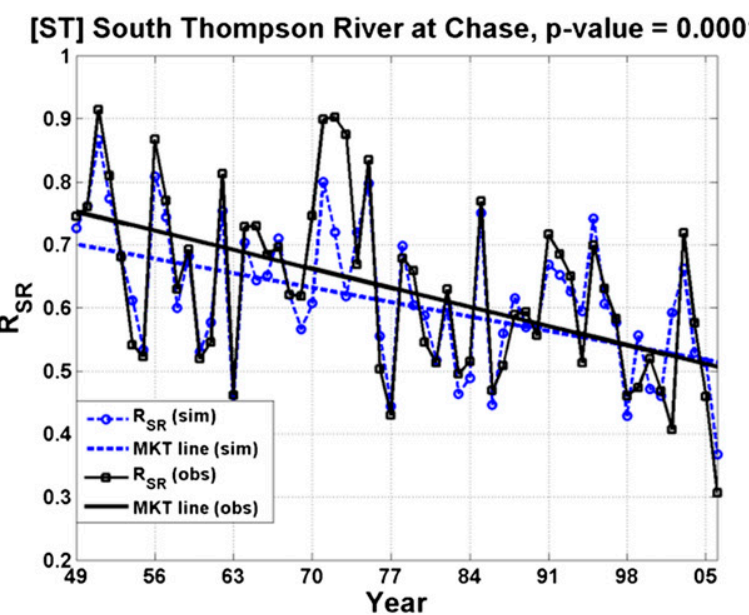

[TN] Thompson River near Spences Bridge, $p$-value $=0.0002$
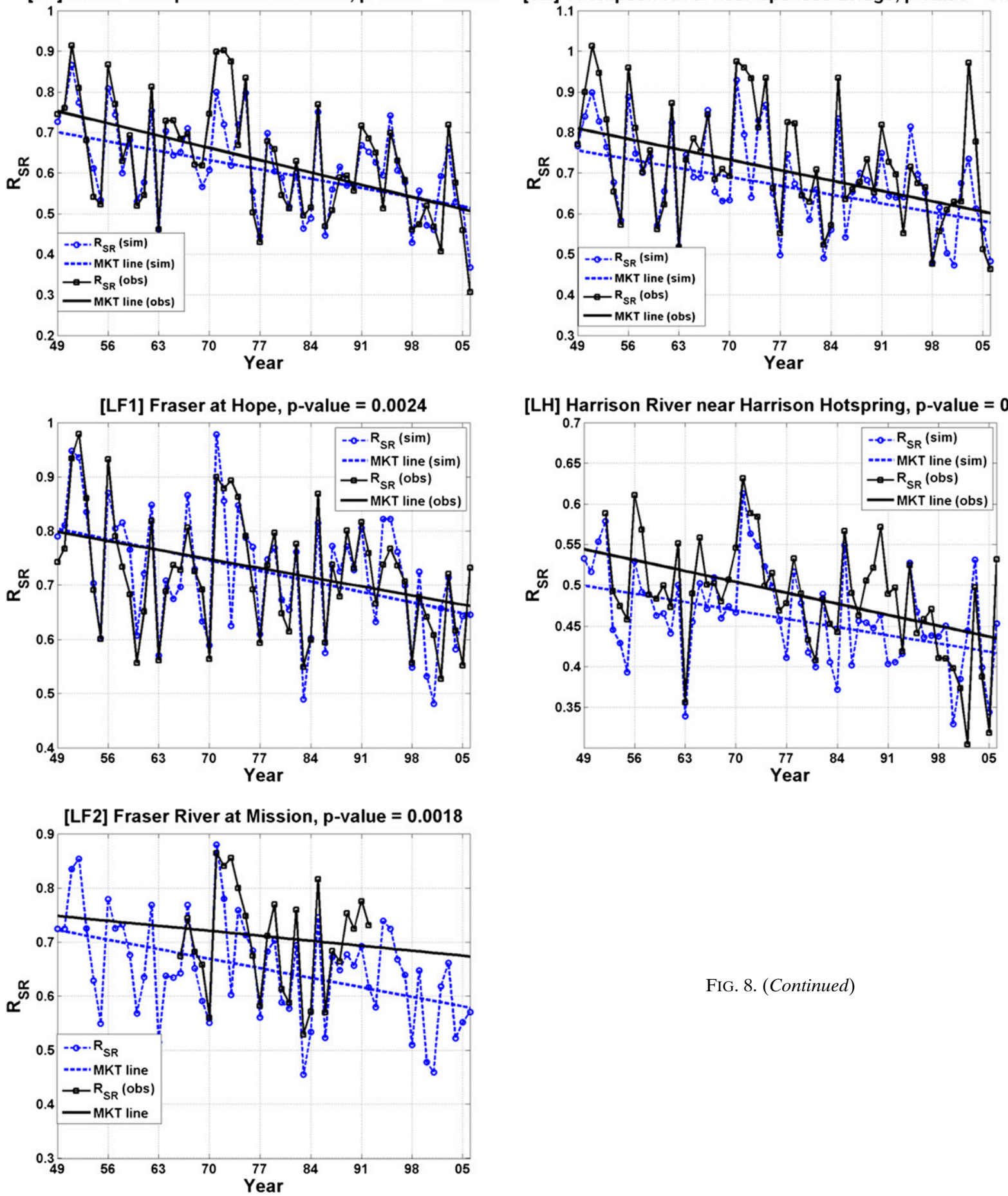

FIG. 8. (Continued)

\section{e. Hydrologic responses to perturbed forcing}

To investigate the Fraser River's (at Hope) hydrologic responses (e.g., $\mathrm{SWE}_{\mathrm{melt}}, R$, and $R_{\mathrm{SR}}$ ) to a changing climate, the forcing datasets are perturbed by

increasing/decreasing air temperatures in increments of $1.0^{\circ}$ and $2.0^{\circ} \mathrm{C}$ and multiplying precipitation by factors of 0.9 and 1.1, respectively. The simulation results suggest that $\mathrm{SWE}_{\text {melt }}$ is largest when the air temperature decreases by $2^{\circ} \mathrm{C}$ (Fig. 10a), leading to greater runoff. 
TABLE 5. Trend of $R_{\mathrm{SR}}$ and their $p$ values from 1949 to 2006 using the Mann-Kendall test.

\begin{tabular}{cccc}
\hline \hline Watershed & Trend $\left[(58 \mathrm{yr})^{-1}\right]$ & $p$ value & Change $(\%)$ \\
\hline SU & -0.05 & 0.1436 & -11 \\
NA & -0.08 & 0.0989 & -17 \\
UF & -0.10 & 0.0053 & -19 \\
QU & -0.12 & 0.0108 & -17 \\
CH & -0.08 & 0.0002 & -15 \\
NT & -0.10 & 0.0108 & -17 \\
ST & -0.18 & 0.0001 & -26 \\
TN & -0.17 & 0.0002 & -23 \\
LF1 & -0.15 & 0.0024 & -19 \\
LH & -0.09 & 0.0012 & -16 \\
LF2 & -0.09 & 0.0018 & -20 \\
\hline
\end{tabular}

Nonetheless, $R_{\mathrm{SR}}$ is barely affected, owing to proportional changes in SWE and runoff. However, in the 1990s and $2000 \mathrm{~s}$, an increase of $2^{\circ} \mathrm{C}$ yields the largest decrease of $R_{\mathrm{SR}}$ compared to previous decades. For example, the difference of $R_{\mathrm{SR}}$ between $-2^{\circ} \mathrm{C}$ and $+2^{\circ} \mathrm{C}$ is about 0.2 . This suggests that the snow deposition diminishes with warmer air temperature but runoff does not decrease as much. Therefore, the increasing air temperature mostly contributes to the attenuation of $R_{\mathrm{SR}}$, especially since the $1990 \mathrm{~s}$ across the FRB.

Fig. 11 shows the results from perturbed precipitation forcings. $\mathrm{SWE}_{\text {melt }}$ increases as precipitation increases and as more snow accumulates when the winter snowfall is enhanced. More runoff is also generated by the increase of precipitation. The amplification in runoff is attributed to the fact that Fraser River is mostly driven by spring snowmelt. If precipitation is increased, more seasonal snowpack is deposited in the mountains. Because snowfall is also amplified during the wintertime when the snowmelt season starts as temperatures rise, more runoff driven by snowmelt is likely to happen. On the other hand, larger precipitation (1.1 multiplicative factor) imposed to the FRB shows less snow contribution to the runoff in the FRB (Fig. 10c). This inverse relationship between precipitation and $R_{\mathrm{SR}}$ implies that the change of $\mathrm{SWE}_{\text {melt }}$ is not as large as the change in runoff induced by precipitation.

In addition to separate perturbations of air temperature and precipitation, a set of simultaneous perturbations is also conducted. Table 6 shows average values and trends of $R_{\mathrm{SR}}$ along the 58 years with precipitation times 0.9 and 1.1 with air temperature in increments of $1.0^{\circ}$ and $2.0^{\circ} \mathrm{C}$. As precipitation and air temperature diminishes, the $R_{\mathrm{SR}}$ becomes amplified, indicating the snowmelt contribution to the runoff becomes significant. The smallest value of 0.64 of $R_{\mathrm{SR}}$ occurs when the precipitation is multiplied by 1.1 and the air temperature is increased by $2^{\circ} \mathrm{C}$. This suggests that warming temperatures suppress the snowmelt contribution because of less deposition of snowpack. The largest $R_{\mathrm{SR}}$ of 0.81 occurs when the air temperature decreases by $2^{\circ} \mathrm{C}$ with no perturbation of precipitation. Because the VIC model determines the snowfall based on a lapse rate of air temperature across the elevation bands, the cooler air temperature amplifies the snowfall fraction accumulated within a grid cell, increasing the contribution of the snowmelt to the runoff.

\section{Summary and conclusions}

VIC, a macroscale surface hydrology model, is applied to Canada's Fraser River basin from water year 1949 to

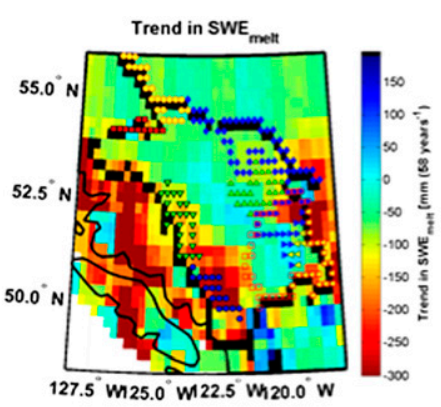

(a)

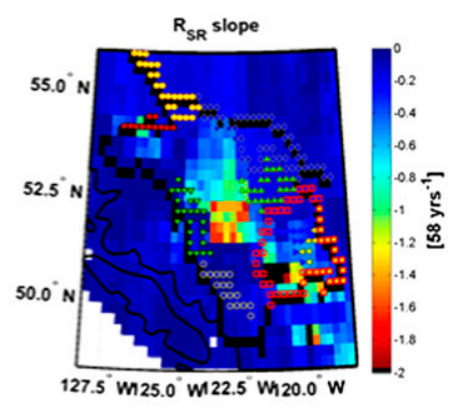

(b)

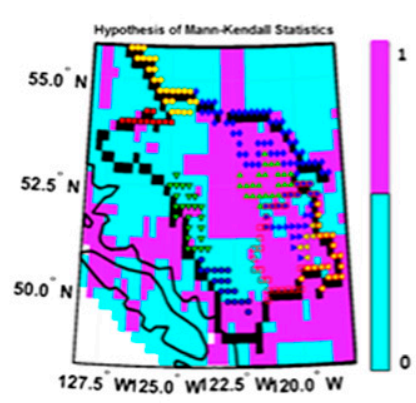

(c)
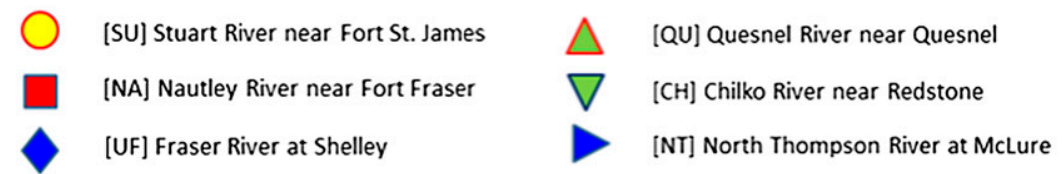

[ST] South Thompson River at Chase

[TN] Thompson River near Spences Bridge

[LH] Harrison River near Harrison Hot Spring

FIG. 9. (a) Spatial distribution of $\mathrm{SWE}_{\text {melt }}$ from model results, (b) its linear trend, and (c) rejection result against a "no trend" hypothesis ( $1=$ decreasing trend, $0=$ no trend $), 1949-2006$. 


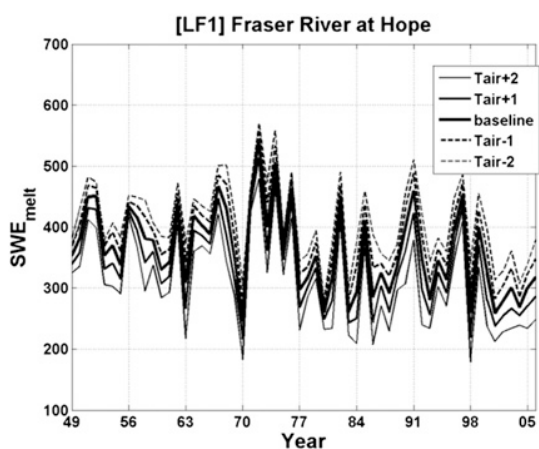

(a)

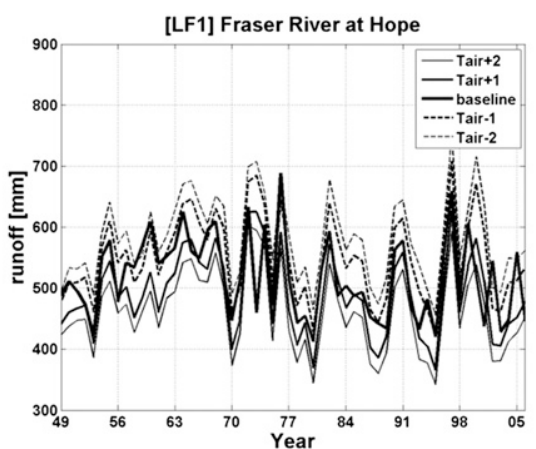

(b)

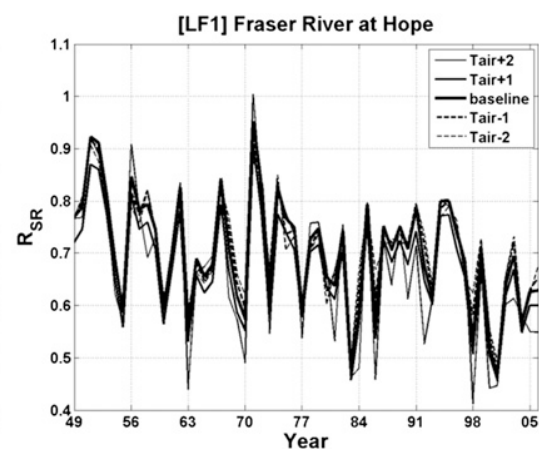

(c)

FIG. 10. Time series of (a) $\mathrm{SWE}_{\text {melt }}$, (b) $R$, and (c) $R_{\mathrm{SR}}$ when the air temperature forcing is perturbed by increments of $\pm 1.0^{\circ} \mathrm{C}$ and $\pm 2.0^{\circ} \mathrm{C}$ for LF1, 1949-2006.

2006. The simulations reveal that a warming climate results in significant changes in the hydrological regime of the FRB. Indeed, from 1949 to 2006, the VIC simulations yield a $19 \%$ decline in the contribution of snow to runoff generation $\left(R_{\mathrm{SR}}\right)$ for the main stem Fraser River at Hope, BC. Similarly, statistically significant reductions in the contribution of snow to runoff generation arise in 9 out of 11 of the FRB's major subwatersheds, owing to a $1.4^{\circ} \mathrm{C}$ overall rise in mean annual air temperatures over the study period. Thus, declining snowpacks have altered the timing and amount of runoff seen in the FRB in recent decades, similar to trends observed in the northwestern United States (Mote et al. 2005; Stewart et al. 2005).

Although the VIC simulations compare favorably with observations of both SWE and streamflow across the FRB, limitations remain to this study. Despite using high-resolution elevation bands $(100 \mathrm{~m})$ critical in the mountainous FRB, the spatial resolution of $0.25^{\circ}$ is relatively coarse and will be improved in future work. Similarly, the daily time step used in the VIC model integrations may be increased to hourly in future efforts. The accuracy of the forcing data at the model grid resolution and its modification to consider lapse rate effects across elevation bands may also introduce uncertainties in the VIC model simulations. Finally, the calibration process may yield good simulation results while not representing the actual physical conditions of the basin such as soil layer thicknesses. Nonetheless, the high NSE coefficients of the VIC simulations for SWE and runoff compared to observations offer promising indications of the model's ability to resolve hydrological processes in complex and varied terrain.

As a one of the world's largest salmon rivers, the Fraser and its tributaries are vital to the ecological functioning, cultural values, and economy of western Canada. Climate change may significantly degrade the success rates of upriver salmon migrations into the inland sections of the FRB as well as spawning rates (Eliason et al. 2011). More abundant rainfall will scour the riverbeds, resulting in deterioration in salmon spawning habitats (McNeil 1966; Steen and Quinn 1999). Warmer water temperatures and stronger fluctuations

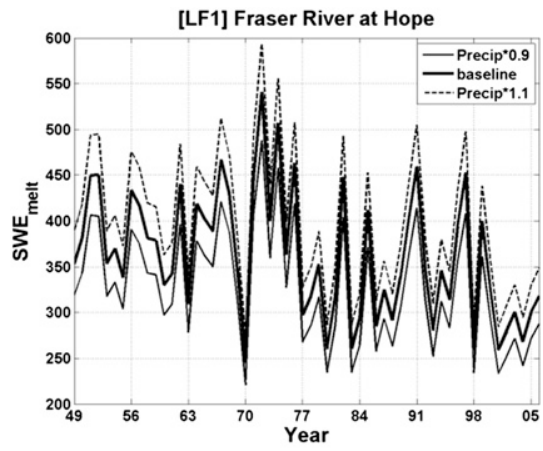

(a)

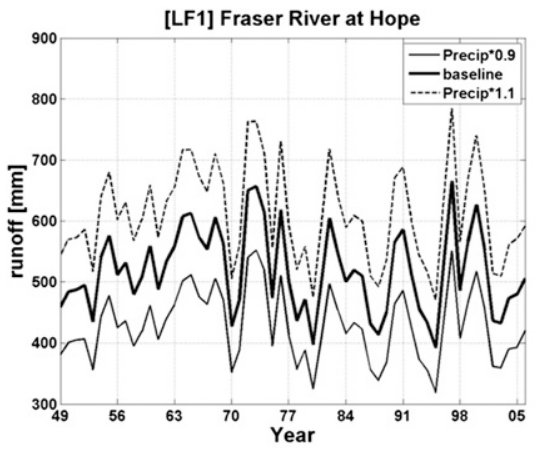

(b)

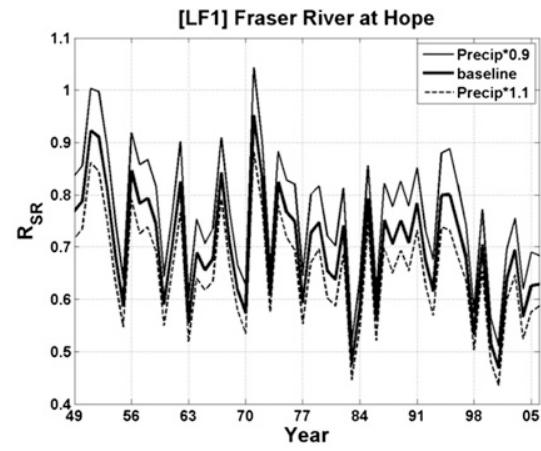

(c)

FIG. 11. Time series of (a) $\mathrm{SWE}_{\text {melt }}$, (b) $R$, and (c) $R_{\mathrm{SR}}$ when the precipitation forcing is perturbed by multiplicative factors of 1.1 and 0.9 for LF1, 1949-2006. 
TABLE 6. Average values and slopes of $R_{\mathrm{SR}}$ of perturbed air temperature and precipitation, 1949-2006 (all Mann-Kendall test $p$ values are below 0.05 , suggesting significant decreasing trend).

\begin{tabular}{lccccc}
\hline \hline \multicolumn{1}{c}{$\operatorname{Avg}\left(R_{\mathrm{SR}}\right)$} & $T_{\text {air }}-2^{\circ} \mathrm{C}$ & $T_{\text {air }}-1{ }^{\circ} \mathrm{C}$ & $T_{\text {air }}$ & $T_{\text {air }}+1^{\circ} \mathrm{C}$ & $T_{\text {air }}+2^{\circ} \mathrm{C}$ \\
\hline Precipitation $\times 0.9$ & 0.78 & 0.79 & 0.87 & 0.78 & 0.76 \\
Precipitation & 0.80 & 0.73 & 0.72 & 0.78 & 0.74 \\
Precipitation $\times 1.1$ & 0.68 & 0.68 & 0.75 & 0.66 & 0.64 \\
Trend $\left[(58 \text { yr })^{-1}\right]$ & $T_{\text {air }}-2^{\circ} \mathrm{C}$ & $T_{\text {air }}-1{ }^{\circ} \mathrm{C}$ & $T_{\text {air }}$ & $T_{\text {air }}+1^{\circ} \mathrm{C}$ & $T_{\text {air }}+2^{\circ} \mathrm{C}$ \\
\hline Precipitation $\times 0.9$ & -0.002 & -0.003 & -0.003 & -0.003 & -0.004 \\
Precipitation & -0.002 & -0.002 & -0.003 & -0.004 & -0.005 \\
Precipitation $\times 1.1$ & -0.002 & -0.002 & -0.003 & -0.003 & -0.004 \\
\hline
\end{tabular}

in flows may also impede future salmon migrations (Morrison et al. 2002; Déry et al. 2012). Thus, future work will investigate twenty-first-century climate change scenarios and their possible impacts on the hydrology of the FRB, including changes in snowpack accumulation. This will provide critical information on the range of possible future flows and their timing and hence establish possible impacts on Fraser River keystone species such as salmon.

Acknowledgments. Thanks to Justin Sheffield (Princeton) for providing the soil and vegetation parameters for the VIC model application. Thanks for the valuable comments from the Pacific Climate Impacts Consortium at the University of Victoria. We also gratefully acknowledge the continued support from Dennis Lettenmaier and the Land Surface Hydrology research group at University of Washington in running the VIC model. Financial support was provided by the Government of Canada's CRC program and NSERC Discovery and Accelerator Grants to Stephen Déry and the Canadian Sea Ice and Snow Evolution (CanSISE) network funded by NSERC. Thanks to three anonymous reviewers and the handling editor for constructive comments that greatly improved the paper.

\section{REFERENCES}

Adam, J. C., and D. P. Lettenmaier, 2003: Adjustment of global gridded precipitation for systematic bias. J. Geophys. Res., 108, 4257, doi:10.1029/2002JD002499.

- , and - 2008: Application of new precipitation and reconstructed streamflow products to streamflow trend attribution in northern Eurasia. J. Climate, 21, 1807-1828, doi:10.1175/2007JCLI1535.1.

_ , E. A. Clark, D. P. Lettenmaier, and E. F. Wood, 2006: Correction of global precipitation products for orographic effects. J. Climate, 19, 15-38, doi:10.1175/JCLI3604.1.

BC Ministry of Forests, Lands, and Natural Resource Operations, 2014: Automated Snow Pillow Data. [Available online at http://bcrfc.env.gov.bc.ca/data/asp/.]

Beamish, R. J., M. Henderson, and H. Regier, 1997: Impacts of climate change on the fishes of British Columbia. Responding to Global Climate Change in British Columbia and Yukon, Vol. 1, E. Taylor and B. Taylor, Eds., BC Ministry of Environment, Lands and Parks, 12-1-12-16.

Benke, A. C., and C. E. Cushing, 2005: Background and approach. Rivers of North America, A. C. Benke and C. E. Cushing, Eds., Elsevier, 1-18.

Bocking, R. C., 1997: Mighty River: A Portrait of the Fraser. Douglas and McIntyre, $294 \mathrm{pp}$.

Bowling, L. C., and D. P. Lettenmaier, 2010: Modeling the effects of lakes and wetlands on the water balance of Arctic environments. J. Hydrometeor., 11, 276-295, doi:10.1175/ 2009JHM1084.1.

— J. W. Pomeroy, and D. P. Lettenmaier, 2004: Parameterization of blowing-snow sublimation in a macroscale hydrology model. J. Hydrometeor., 5, 745-762, doi:10.1175/ 1525-7541(2004)005<0745:POBSIA >2.0.CO;2.

Cherkauer, K. A., L. C. Bowling, and D. P. Lettenmaier, 2003: Variable infiltration capacity cold land process model updates. Global Planet. Change, 38, 151-159, doi:10.1016/ S0921-8181(03)00025-0.

Choi, G., D. A. Robinson, and S. Kang, 2010: Changing Northern Hemisphere snow seasons. J. Climate, 23, 5305-5310, doi:10.1175/2010JCLI3644.1.

Cosby, B. J., G. M. Hornberger, R. B. Ckapp, and T. R. Ginn, 1984: A statistical exploration of the relationship of soil moisture characteristics to the physical properties of soils. Water Resour. Res., 20, 682-690, doi:10.1029/WR020i006p00682.

Danard, M., and T. S. Murty, 1994: On recent climate trends in selected salmon-hatching areas of British Columbia. J. Climate, 7, 1803-1808, doi:10.1175/1520-0442(1994)007<1803: ORCTIS $>2.0 . \mathrm{CO} ; 2$.

Déry, S. J., J. Sheffield, and E. F. Wood, 2005a: Connectivity between Eurasian snow cover extent and Canadian snow water equivalent and river discharge. J. Geophys. Res., 110, D23106, doi:10.1029/2005JD006173.

, M. Stieglitz, E. C. McKenna, and E. F. Wood, 2005b: Characteristics and trends of river discharge into Hudson, James, and Ungava Bays, 1964-2000. J. Climate, 18, 2540-2557, doi:10.1175/JCLI3440.1.

— M. A. Hernández-Henríquez, P. N. Owens, M. W. Parkes, and E. L. Petticrew, 2012: A century of hydrological variability and trends in the Fraser River basin. Environ. Res. Lett., 7, 024019, doi:10.1088/1748-9326/7/2/024019.

Elder, K., J. Dozier, and J. Michaelsen, 1991: Snow accumulation and distribution in an alpine watershed. Water Resour. Res., 27, 1541-1552, doi:10.1029/91WR00506. 
Eliason, E. J., and Coauthors, 2011: Differences in thermal tolerance among sockeye salmon populations. Science, 332, 109112, doi:10.1126/science.1199158.

Environment Canada, cited 2014: Climate database. [Available online at http://climate.weather.gc.ca.]

Evendon, M. D., 2004: Fish versus Power: An Environmental History of the Fraser River. Cambridge University Press, 309 pp.

FAO, 2003: Digital Soil Map of the World and Derived Soil Properties. FAO Land and Water Digital Media Series, No. 1, Food and Agriculture Organization, CD-ROM.

Ferrari, M. R., J. R. Miller, and G. L. Russell, 2007: Modeling changes in summer temperature of the Fraser River during the next century. J. Hydrol., 342, 336-346, doi:10.1016/ j.jhydrol.2007.06.002.

Fraser Basin Council, 2006: Bridge between nations: A history of first nations in the Fraser River basin. Fraser Basin Council, 24 pp. [Available online at www.fraserbasin.bc.ca/_Library/ Ab_NonAb_Relations/bridge_between_nations.pdf.]

_ 2009: Sustainability snapshot 4: The many faces of sustainability. 2009 State of the Fraser Basin Rep., Fraser Basin Council, Vancouver, Canada. [Available online at www. fraserbasin.bc.ca/_Library/Comm_Indicators/report_ss4_ 2009.pdf.]

Goldberg, D., 1989: Genetic Algorithms in Search, Optimization and Machine Learning. Addison-Wesley Publishing, 412 pp.

Haddeland, I., T. Skaugen, and D. P. Lettenmaier, 2007: Hydrologic effects of land and water management in North America and Asia: 1700-1992. Hydrol. Earth Syst. Sci., 11, 1035-1045, doi:10.5194/hess-11-1035-2007.

Hansen, M. C., R. S. DeFries, J. R. G. Townshend, and R. Sohlberg, 2000: Global land cover classification at $1 \mathrm{~km}$ spatial resolution using a classification tree approach. Int. J. Remote Sens., 21, 1331-1364, doi:10.1080/014311600210209.

Hartman, G. F., 1996: Impacts of growth in resource use and human population on the Nechako River: A major tributary of the Fraser River, British Columbia, Canada. GeoJournal, 40, 147164, doi:10.1007/BF00222540.

Hsieh, W. W., and B. Tang, 2001: Interannual variability of accumulated snow in the Columbia basin, British Columbia. Water Resour. Res., 37, 1753-1759, doi:10.1029/2000WR900410.

Kalnay, E., and Coauthors, 1996: The NCEP/NCAR 40-Year Reanalysis Project. Bull. Amer. Meteor. Soc., 77, 437-471, doi:10.1175/1520-0477(1996)077<0437:TNYRP>2.0.CO;2.

Kendall, M. G., 1970: Rank Correlation Methods. 4th ed. Griffin, $202 \mathrm{pp}$

Liang, X., D. P. Lettenmaier, E. F. Wood, and S. J. Burges, 1994: A simple hydrologically based model of land-surface water and energy fluxes for general-circulation models. J. Geophys. Res., 99, 14 415-14 428, doi:10.1029/94JD00483.

— E. E. F. Wood, and D. P. Lettenmaier, 1996: Surface soil moisture parameterization of the VIC-2L model: Evaluation and modification. Global Planet. Change, 13, 195-206, doi:10.1016/0921-8181(95)00046-1.

Lohmann, D., R. Nolte-Holube, and E. Raschke, 1996: A large scale horizontal routing model to be coupled to land surface parameterization schemes. Tellus, 48A, 708-721, doi:10.1034/ j.1600-0870.1996.t01-3-00009.x.

, B. Nijssen, and D. P. Lettenmaier, 1998a: Regional scale hydrology: I. Formulation of the VIC-2L model coupled to a routing model. Hydrol. Sci. J., 43, 131-141, doi:10.1080/ 02626669809492107.
,-- , and - 1998b: Regional scale hydrology: II. Application of the VIC-2L model to the Weser River, Germany. Hydrol. Sci. J., 43, 143-158, doi:10.1080/02626669809492108.

Mann, H. B., 1945: Nonparametric tests against trend. Econometrica, 13, 245-259, doi:10.2307/1907187.

Matsuura, K., and C. J. Willmott, 2009: Terrestrial precipitation: 1900-2008 gridded monthly time series (version 2.01). Center for Climatic Research, Department of Geography, University of Delaware, Newark, DE, digital media. [Available online at http://climate.geog.udel.edu/ climate/.]

Maurer, E. P., A. W. Wood, J. C. Adam, D. P. Lettenmaier, and B. Nijssen, 2002: A long-term hydrologically based dataset of land surface fluxes and states for the conterminous United States. J. Climate, 15, 3237-3251, doi:10.1175/ 1520-0442(2002)015<3237:ALTHBD>2.0.CO;2.

McNeil, W. J., 1966: Effects of the spawning bed environment on reproduction of pink and chum salmon. Fish. Bull., 65, 495-525. [Available online at http://fishbull.noaa.gov/65-2/ moneil.pdf.]

Mesinger, F., and Coauthors, 2006: North American Regional Reanalysis. Bull. Amer. Meteor. Soc., 87, 343-360, doi:10.1175/ BAMS-87-3-343.

Mitchell, K. E., and Coauthors, 2004: The multi-institution North American Land Data Assimilation System (NLDAS): Utilizing multiple GCIP products and partners in a continental distributed hydrological modeling system. J. Geophys. Res., 109, D07S90, doi:10.1029/2003JD003823.

Moore, R. D., and S. M. Wondzell, 2005: Physical hydrology and the effects of forest harvesting in the Pacific Northwest: A review. J. Amer. Water Resour. Assoc., 41, 763-784, doi:10.1111/j.1752-1688.2005.tb04463.x.

Morrison, J., M. C. Quick, and M. G. G. Foreman, 2002: Climate change in the Fraser River watershed: Flow and temperature projections. J. Hydrol., 263, 230-244, doi:10.1016/ S0022-1694(02)00065-3.

Mote, P. W., A. F. Hamlet, M. P. Clark, and D. P. Lettenmaier, 2005: Declining mountain snowpack in western North America. Bull. Amer. Meteor. Soc., 86, 39-49, doi:10.1175/BAMS-86-1-39.

Myneni, R. B., R. R. Nemani, and S. W. Running, 1997: Estimation of global leaf area index and absorbed PAR using radiative transfer models. IEEE Trans. Geosci. Remote Sens., 35, 1380 1393, doi:10.1109/36.649788.

Nash, J. E., and J. V. Sutcliffe, 1970: River flow forecasting through conceptual models part I-A discussion of principles. $J$. Hydrol., 10, 282-290, doi:10.1016/0022-1694(70)90255-6.

Nijssen, B., G. M. O’Donnell, D. P. Lettenmaier, D. Lohmann, and E. F. Wood, 2001: Predicting the discharge of global rivers. J. Climate, 14, 3307-3323, doi:10.1175/1520-0442(2001)014<3307: PTDOGR $>2.0 . \mathrm{CO} ; 2$.

Park, H., H. Yabuki, and T. Ohata, 2012: Analysis of satellite and model datasets for variability and trends in Arctic snow extent and depth, 1948-2006. Polar Sci., 6, 23-37, doi:10.1016/ j.polar.2011.11.002.

Rand, P. S., and Coauthors, 2006: Effects of river discharge, temperature, and future climates on energetics and mortality of adult migrating Fraser River sockeye salmon. Trans. Amer. Fish. Soc., 135, 655-667, doi:10.1577/T05-023.1.

Schiefer, E., and B. Klinkenberg, 2004: The distribution and morphometry of lakes and reservoirs in British Columbia: A provincial inventory. Can. Geogr., 48, 345-355, doi:10.1111/ j.0008-3658.2004.00064.x.

Sheffield, J., and E. F. Wood, 2007: Characteristics of global and regional drought, 1950-2000: Analysis of soil moisture data 
from off-line simulation of the terrestrial cycle. J. Geophys. Res., 112, D17115, doi:10.1029/2006JD008288.

_ - G. Goteti, and E. F. Wood, 2006: Development of a 50-yr, high resolution global dataset of meteorological forcings for land surface modeling. J. Climate, 19, 3088-3111, doi:10.1175/ JCLI3790.1.

Shi, X., A. W. Wood, and D. P. Lettenmaier, 2008: How essential is hydrologic model calibration to seasonal streamflow forecasting? J. Hydrometeor., 9, 1350-1363, doi:10.1175/ 2008JHM1001.1.

— S. J. Déry, P. Y. Groisman, and D. P. Lettenmaier, 2013: Relationship between recent pan-Arctic snow cover and hydroclimate trends. J. Climate, 26, 2048-2064, doi:10.1175/ JCLI-D-12-00044.1.

Shrestha, R. R., M. A. Schnorbus, A. T. Werner, and A. J. Berland, 2012: Modelling spatial and temporal variability of hydrologic impacts of climate change in the Fraser River basin, British Columbia, Canada. Hydrol. Processes, 26, 1840-1860, doi:10.1002/hyp.9283.

Shukla, S., N. Voisin, and D. P. Lettenmaier, 2012: Value of medium range weather forecasts in the improvement of seasonal hydrologic prediction skill. Hydrol. Earth Syst. Sci., 16, 28252838, doi:10.5194/hess-16-2825-2012.

_ J J. Sheffield, E. F. Wood, and D. P. Lettenmaier, 2013: On the sources of global land surface hydrologic predictability. Hydrol. Earth Syst. Sci., 10, 1987-2013, doi:10.5194/ hessd-10-1987-2013.

Slaymaker, O., 1990: Climate change and erosion processes in mountain regions of western Canada. Mt. Res. Dev., 10,171182, doi: $10.2307 / 3673427$

Steen, R. P., and T. P. Quinn, 1999: Egg burial depth by sockeye salmon (Oncorhynchus nerka): Implications for survival of embryos and natural selection on female body size. Can. J. Zool., 77, 836-841, doi:10.1139/cjz-77-5-836.
Stewart, I. T., D. R. Cayan, and M. D. Dettinger, 2005: Changes toward earlier streamflow timing across western North America. J. Climate, 18, 1136-1155, doi:10.1175/JCLI3321.1.

Tong, J., S. J. Déry, P. L. Jackson, and C. Derksen, 2010: Testing snow water equivalent retrieval algorithms for passive microwave remote sensing in an alpine watershed of western Canada. Can. J. Remote Sens., 36, S74-S86, doi:10.5589/m10-009.

USACE, 1956: Snow hydrology: Summary report of the snow investigations. North Pacific Division, U.S. Army Corps of Engineers, Portland, OR, 462 pp. [Available online at ftp:// ftp.wcc.nrcs.usda.gov/wntsc/H\&H/snow/SnowHydrology COE1956.pdf.]

Vano, J. A., T. Das, and D. P. Lettenmaier, 2012: Hydrologic sensitivities of Colorado River runoff to changes in precipitation and temperature. J. Hydrometeor., 13, 932-949, doi:10.1175/JHM-D-11-069.1.

Wang, A., Y. L. Kaiyuan, and D. P. Lettenmaier, 2008: Integration of the variable infiltration capacity model soil hydrology scheme into the community land model. J. Geophys. Res., 113, D09111, doi:10.1029/2007JD009246.

Water Survey of Canada, 2014: HYDAT database. [Available online at http://www.ec.gc.ca/rhc-wsc/.]

Wu, H., J. S. Kimball, N. Mantua, and J. Stanford, 2011: Automated upscaling of river networks for macroscale hydrological modeling. Water Resour. Res., 47, W03517, doi:10.1029/ 2009WR008871.

Xie, L., and W. W. Hsieh, 1989: Predicting the return migration routes of the Fraser River sockeye salmon (Oncorhynchus nerka). Can. J. Fish. Aquat. Sci., 46, 1287-1292, doi:10.1139/f89-165.

Yapo, P., H. Gupta, and S. Sorooshian, 1998: Multi-objective global optimization for hydrologic models. J. Hydrol., 204, 8397, doi:10.1016/S0022-1694(97)00107-8. 